\title{
Reference Manual for Data Base on Nevada Water-Rights Permits
}

By Kenn D. Cartier and Eva M. Bauer, U.S. Geological Survey, and James L. Farnham, Nevada Division of Water Resources

U.S. GEOLOGICAL SURVEY

Open-File Report 95-452

Prepared in cooperation with the

NEVADA DIVISION OF WATER RESOURCES

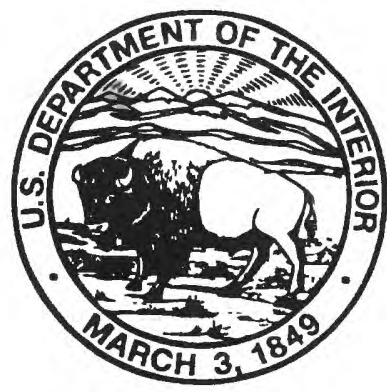

Carson City, Nevada 1995 


\title{
U.S. DEPARTMENT OF THE INTERIOR BRUCE BABBITT, Secretary
}

\author{
U.S. GEOLOGICAL SURVEY \\ GORDON P. EATON, Director
}

Any use of trade names in this publication is for descriptive purposes

only and does not constitute endorsement by the U.S. Government

For additional information

write to:

District Chief

U.S. Geological Survey

333 West Nye Lane, Room 203

Carson City, NV 89706-0866
Copies of this report can be purchased from:

U.S. Geological Survey

Information Services

Box 25286, MS 517

Denver Federal Center

Denver, CO 80225-0046 


\section{CONTENTS}

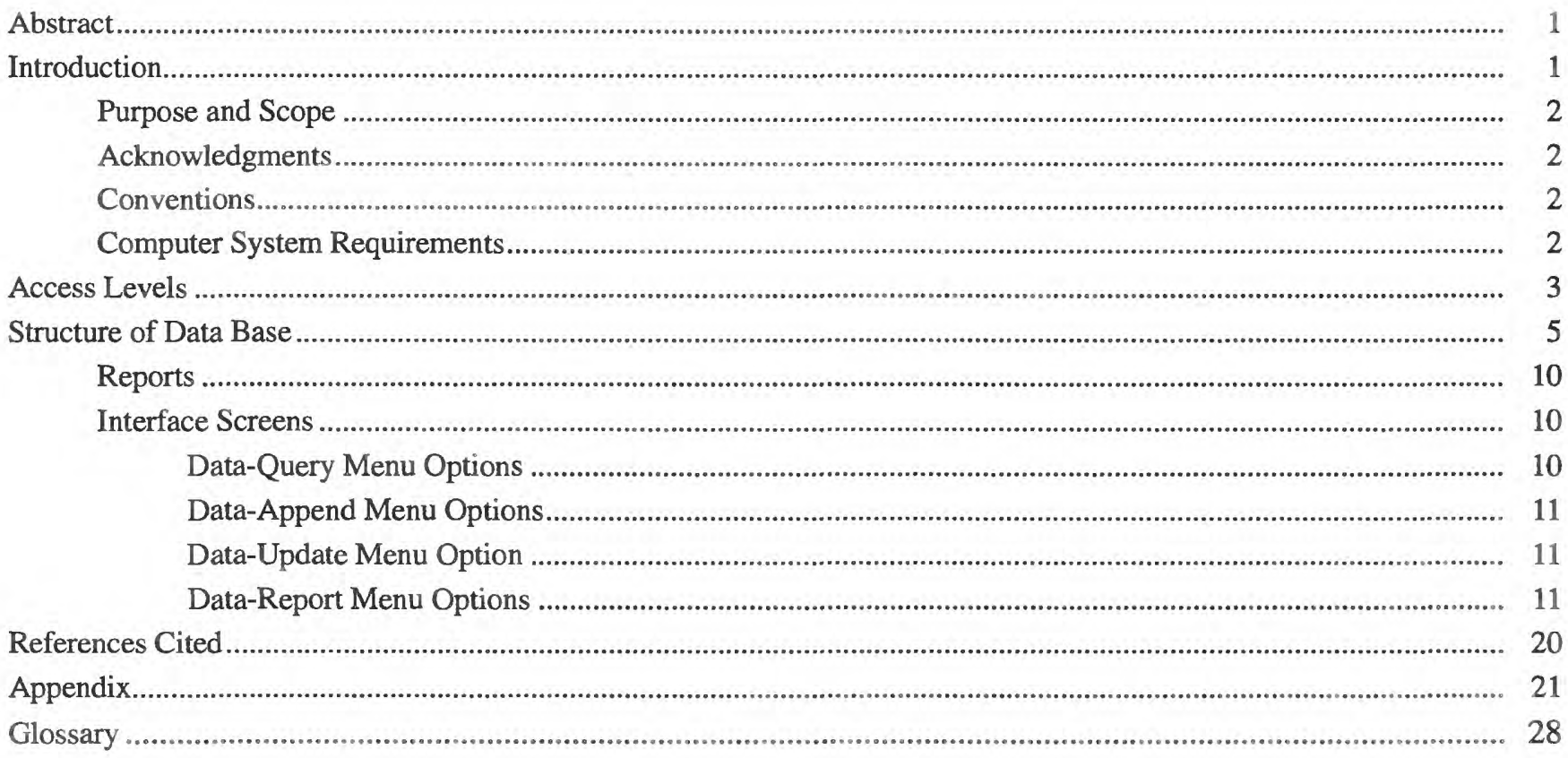

\section{FIGURES}

1-5. Screen images showing main menu for user access:

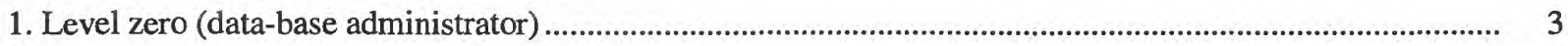

2. Level one (data-entry personnel, full rights) ................................................................................... 4

3. Level two (data-entry personnel, intermediate rights) .................................................................................. 4

4. Level three (data-entry personnel, basic rights) ............................................................................................ 5

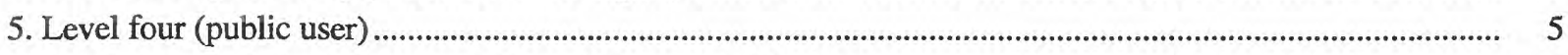

6. Diagram showing relations between tables of the permit data base .................................................................... 6

7-11. Screen images for append mode:

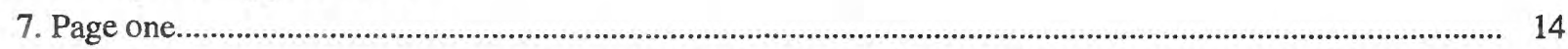

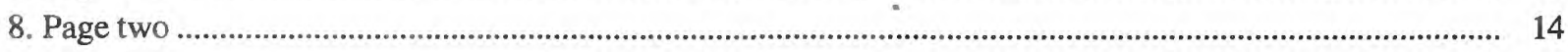

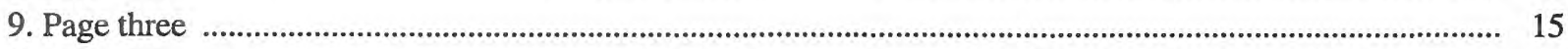

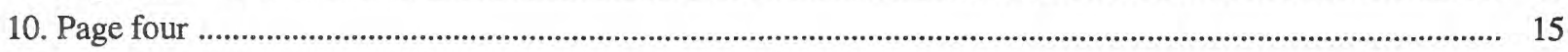

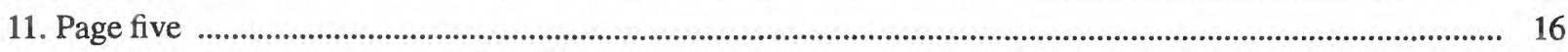

12-15. Screen images showing column headings for:

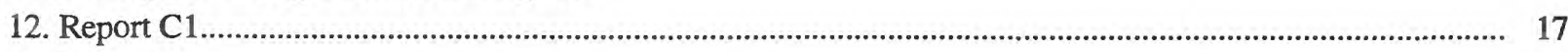

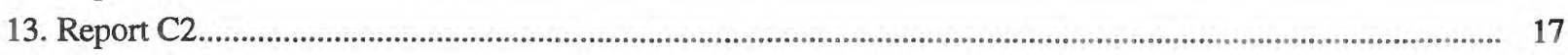

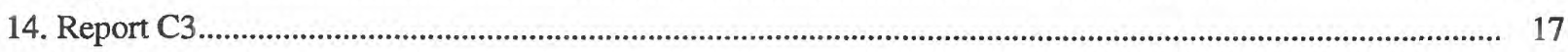

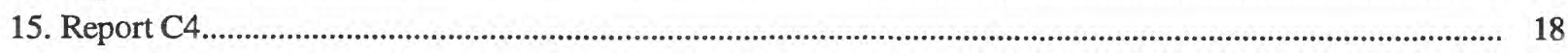

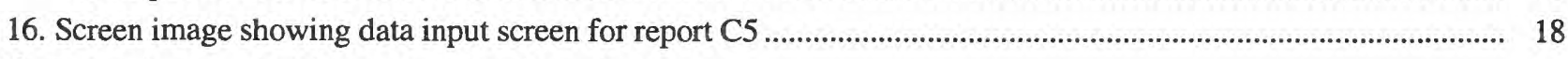

17-19. Screen images showing column headings for:

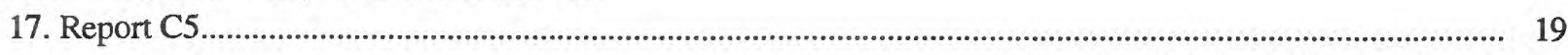

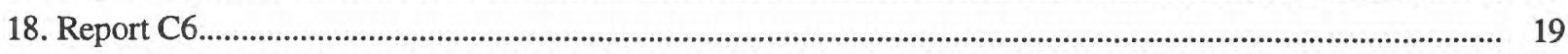

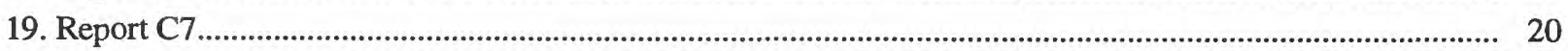




\section{TABLES}

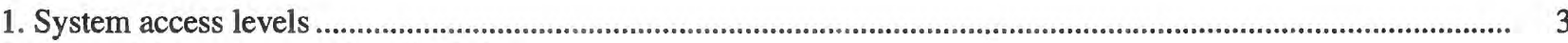

2-5. General description of data fields for:

2. Main (main) table.

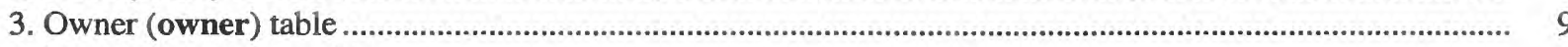

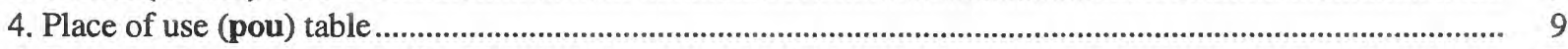

5. Supplemental (supplement) table ................................................................................................. 10

6-9. Field description for data-base tables:

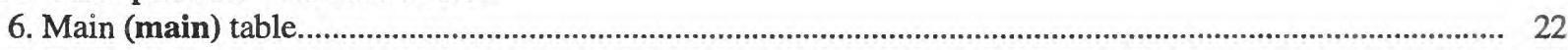

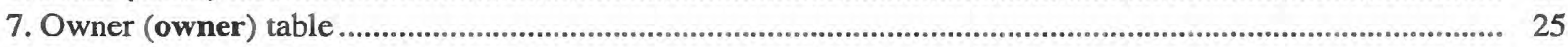

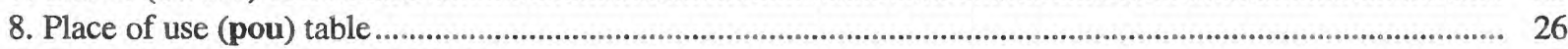

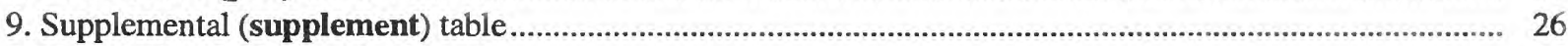

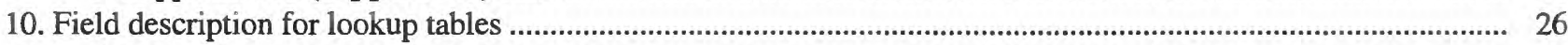

11-14. Codes used for:

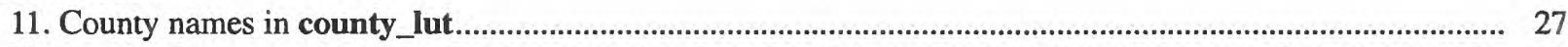

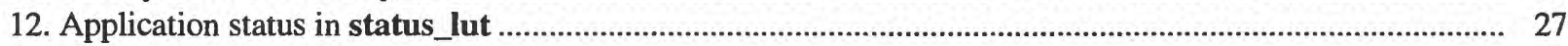

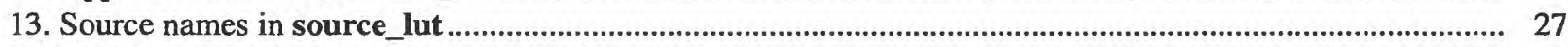

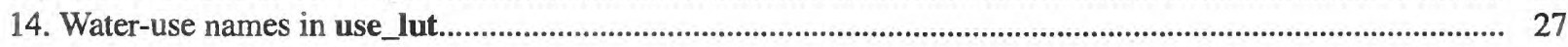




\title{
Reference Manual for Data Base on Nevada Water-Rights Permits
}

\author{
by Kenn D. Cartier and Eva M. Bauer, U.S. Geological Survey, and \\ James L. Farnham, Nevada Division of Water Resources
}

\section{ABSTRACT}

The U.S. Geological Survey and Nevada Division of Water Resources have cooperatively developed and implemented a data-base system for managing water-rights permit information for the State of Nevada. The Water-Rights Permit data base is part of an integrated system of computer data bases using the Ingres Relational Data-Base Management System, which allows efficient storage and access to water information from the State Engineer's office. The data base contains a main table, three ancillary tables, and five lookup tables, as well as a menu-driven system for entering, updating, and reporting on the data. This reference guide outlines the general functions of the system and provides a brief description of data tables and data-entry screens.

\section{INTRODUCTION}

The U.S. Geological Survey (USGS) and Nevada Division of Water Resources (NDWR) have developed a system of three integrated data bases for water-rights permit information, wateruse information, and well-log data. This report documents one of the three data bases, the waterrights permit data base.

The Water-Rights Permit data-base system manages information including water-rights ownership, point of diversion, place of use, diversion rates, well logs, and manner of use. The State government uses the system for administration of water rights and computation of water use within the State; the USGS uses the water-rights information for water-inventory and water-use studies. The data-base system is written in the Ingres Fourth Generation Language (4GL) with the formsbased user-interface program, Application By Forms (ABF). The user interacts with the application through screen menus consisting of four major components: routines for entering data and updating the data base, for making single-record queries, for compiling and producing reports, and utility routines for managing the data base. Data entry is validated using both forms-based and 4GL-based routines.

The current Ingres version of the Water-Rights Permit data-base system was designed to replace a system previously operated by the State of Nevada on a mainframe computer using the COBOL language. The new system allows the State to reduce operating costs and to have greater control over data quality, data access, and report generation. The new system gives USGS a data base that is more accessible for water-use investigations and for integration with the USGS National Water Information System (NWIS) data base.

The computer hardware used by the State consists of a network of non-graphics and graphics terminals connected to a UNIX-based file server. Because most users have access only to a textbased terminal, the application was developed using text-based 4GL. Coding was completed by USGS staff, working closely with NDWR staff to develop the specifications. 


\section{Purpose and Scope}

This document serves as a reference guide to the Water-Rights Permit data-base system, developed for the NDWR by the USGS. This guide outlines the general functions of the system and provides a brief description of data tables and data-entry screens. This guide was written assuming that the user is familiar with NDWR's permit process and has been instructed in the use of the database system. This guide is not intended for the novice user and does not provide detailed instructions for data input or retrieval. It is not a programming guide and does not describe the system's underlying code.

Many of the concepts and terms used in this report and the data-base application are described in reports and unpublished documents by the Nevada Department of Conservation and Natural Resources. These include Water Words Dictionary (Nevada Division of Water Planning, 1994), Nevada Water Laws (Nevada Division of Water Resources, 1993), Water for Nevada (Nevada State Engineer's Office, 1974), Permit Terms (Nevada State Engineer's Office, written commun., [1995]), and Summary of Statutory Procedure in Making Application for a Water Right and Filing Proofs of Appropriation and Fees Set by Statute (Nevada Division of Water Resources, 1994).

The Water-Rights Permit system has been used successfully for several years by NDWR for the daily management of water-permit information. Although the software has been tested, the USGS and NDWR assume no responsibility for errors or omissions, or for damages resulting from the use of the system.

\section{Acknowledgments}

The authors acknowledge several individuals for their contribution to the Water-Rights Permit data-base system. John C. Watson of the U.S. Geological Survey worked on the data-base tables and application. Tracy W. Taylor, P.E., and David J. Modricker, P.E., of the Nevada Division of Water Resources helped with the data specifications.

\section{Conventions}

Bold lower case text, such as main, is used to identify data-base table names. Bold uppercase text, such as APP\#, is used to identify data-field names in a table. Nonbold uppercase text in quotes, such as "SOURCE," is used to identify report names and column headings in reports. Nonbold uppercase text in italics, such as CHANGE BY, is used to identify remarks in a data-base report.

\section{Computer System Requirements}

The Water-Rights Permit data-base system currently operates on a Data General AViiON 5200 file server running a UNIX-based operating system. Ingres Relational Data-Base Management System software is required. The user interface can be executed using either a non-graphics terminal or an X-based terminal. The data-base system was written for the State of Nevada's permitting process and all data ranges and specifications are in accordance with State requirements. 


\section{ACCESS LEVELS}

The Water-Rights Permit application runs at several access levels. These levels of permission control access to the data, access to application routines, and screen displays. The system access levels are summarized in table 1 .

Table 1. System access levels

\begin{tabular}{|c|l|c|c|c|c|c|}
\hline $\begin{array}{c}\text { Access } \\
\text { level }\end{array}$ & \multicolumn{1}{|c|}{$\begin{array}{c}\text { User } \\
\text { description }\end{array}$} & $\begin{array}{c}\text { Data } \\
\text { retrieval }\end{array}$ & $\begin{array}{c}\text { Data } \\
\text { update }\end{array}$ & $\begin{array}{c}\text { Duty- } \\
\text { reports }\end{array}$ & $\begin{array}{c}\text { Dalance } \\
\text { update }\end{array}$ & $\begin{array}{c}\text { Data base } \\
\text { optimization }\end{array}$ \\
\hline 0 & Data base administrator & no & no & no & no & yes \\
\hline 1 & Data-entry personnel, full rights & yes & yes & yes & yes & no \\
\hline 2 & Data-entry personnel, intermediate rights & yes & yes & yes & no & no \\
\hline 3 & Data-entry personnel, basic rights & yes & yes & no & no & no \\
\hline 4 & Public user & yes & no & no & no & no \\
\hline
\end{tabular}

Access level zero is intended for the data-base administrator. The administrator can establish or modify information such as user name, access level, and default printer. The data-base administrator also can optimize the data-base tables for maximum system performance, delete records, and update the application status. The Main menu screen displayed for a user with access level zero is shown in figure 1.

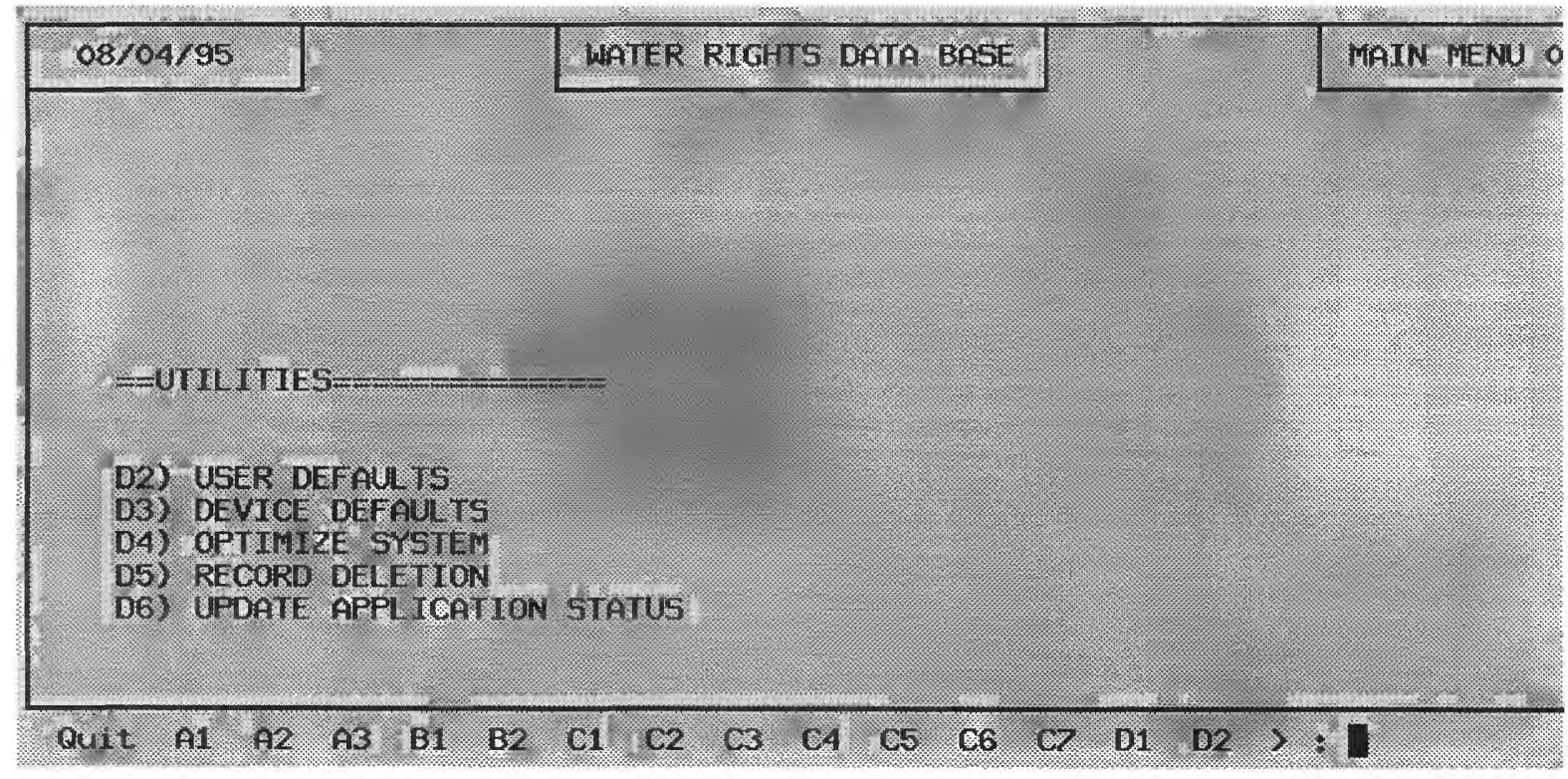

Figure 1. Main menu for user-access level zero (data-base administrator).

Access level one is for data-entry personnel who have full rights and access level two is for data-entry personnel who have intermediate rights. The user with access level one or two can perform data queries, append, and update data and in addition can display and print data reports. The reports include quality-control lists, data summaries, and customized queries. Access level one also allows the user to force changes to the diversion rate-balance field and the duty-balance field. The Main menu screen displayed for a user with access level one is shown in figure 2. The Main menu screen for access level two is shown in figure 3. 


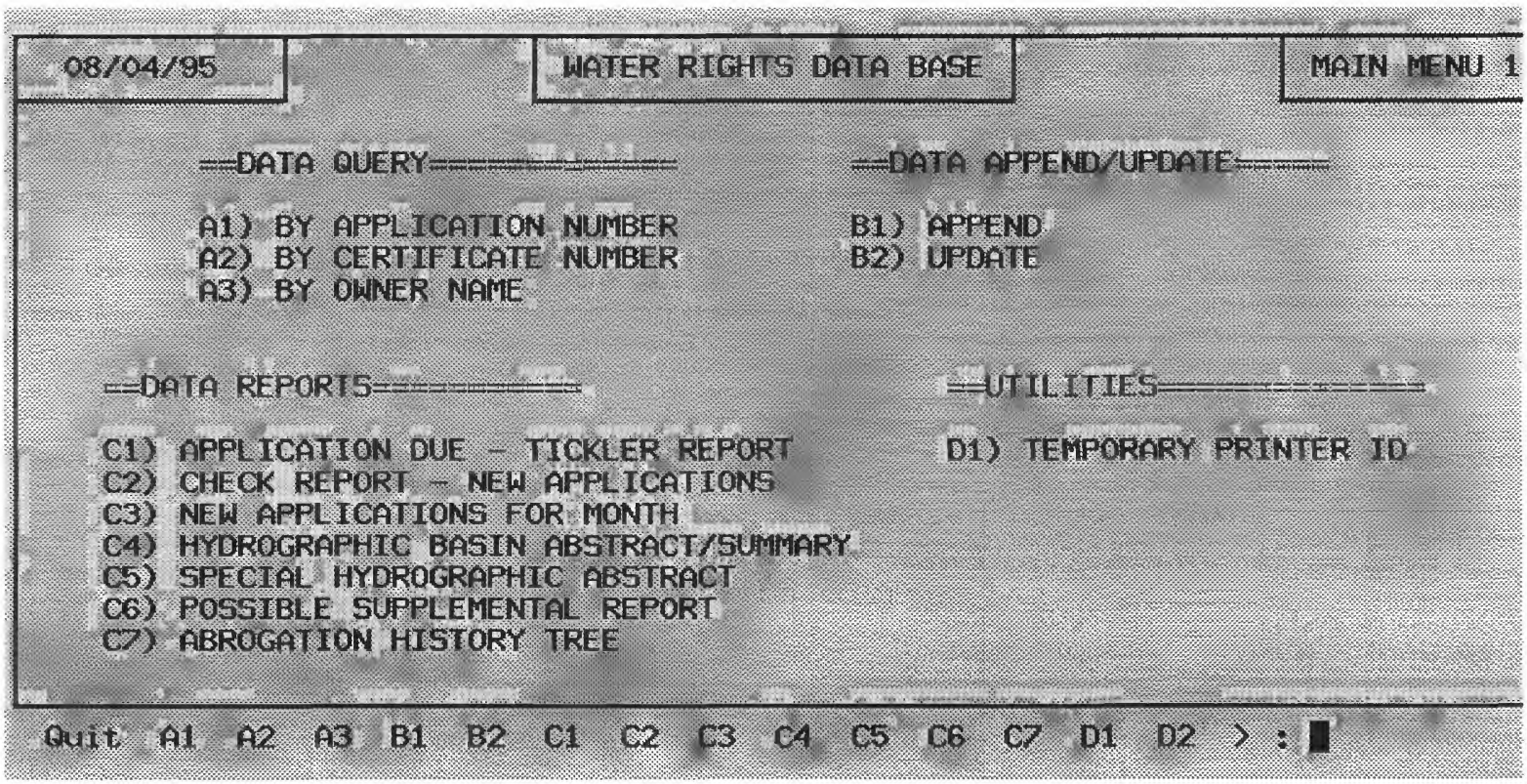

Figure 2. Main menu for user-access level one (data-entry personnel, full rights).

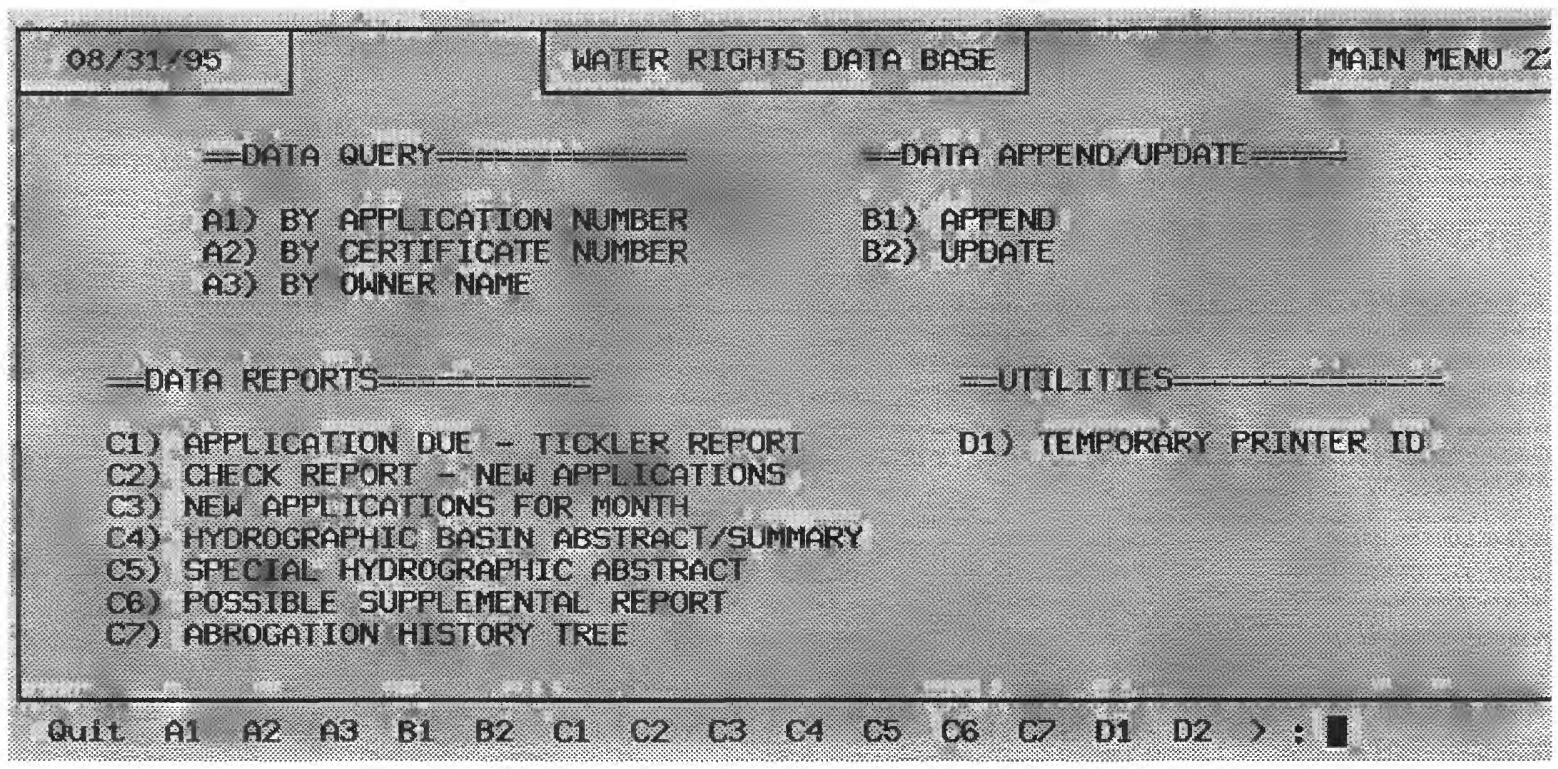

Figure 3. Main menu for user-access level two (data-entry personnel, intermediate rights).

Access level three is for data-entry personnel who have basic rights. The user can perform data queries for specific records, append, and update data. The Main menu screen displayed for a user with access level three is shown in figure 4.

Access level four is for public users and is the most restricted level. The user can make only limited data queries. At this level, public users can search for water-rights permits by several criteria, including application number and owner's name, but are not allowed to modify the data base, view confidential information, or generate reports. The Main menu screen displayed for a user with access level four is shown in figure 5 . 


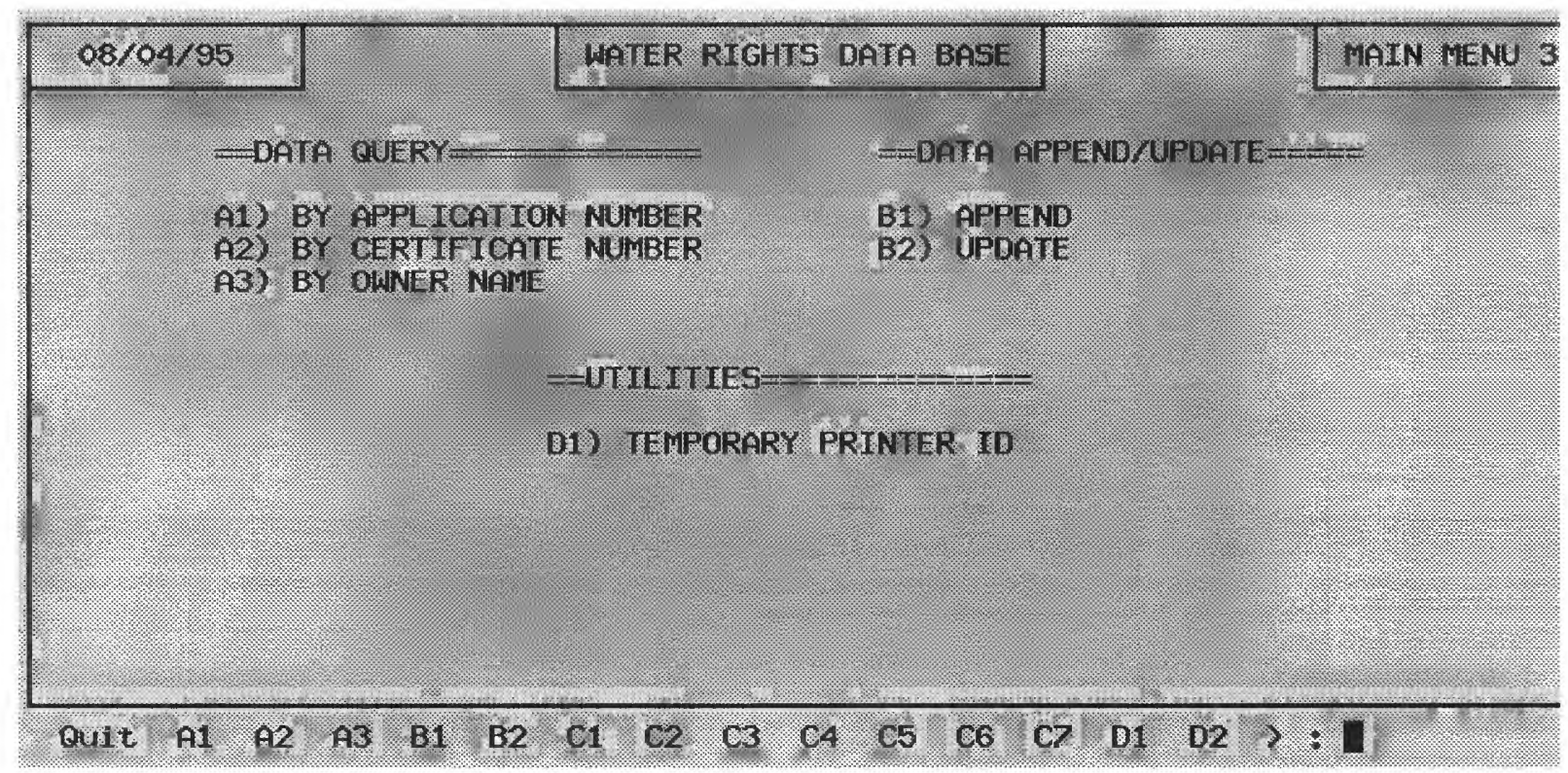

Figure 4. Main menu for user-access level three (data-entry personnel, basic rights).

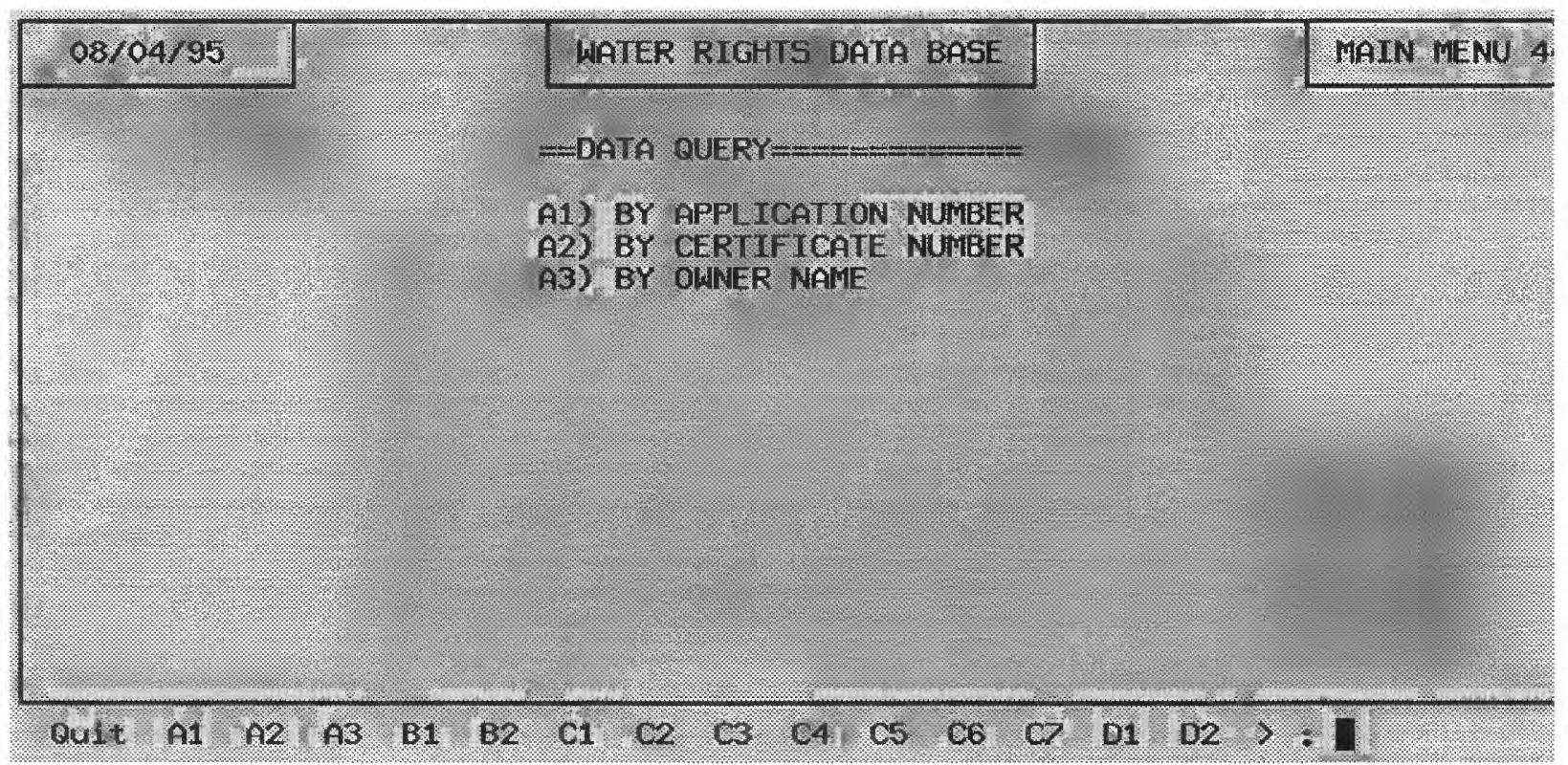

Figure 5. Main menu for user-access level four (public user).

\section{STRUCTURE OF DATA BASE}

The Ingres data base for the Water-Rights Permit system consists of a main table, three ancillary tables, five lookup tables, and three system-maintenance tables. The main table (main) stores most of the water-rights information. The ancillary tables (owner, pou, and supplement) contain information about water-rights ownership, place of use, and supplemental sources of water. The ancillary tables are joined to the main table through one-to-many relations. The lookup tables (basin_lut, county_lut, source_lut, status_lut, and use_lut) give the user a list of valid parameters for particular fields and provide the fully expanded name for abbreviations used in the main and ancillary tables. The system-maintenance tables (defaults_device, defaults_user, and error_messages) store user and printer information and system error messages. The relation between the tables in the permit data base is shown in figure 6. 


\section{Nevada Water-Rights Permit Data Base}

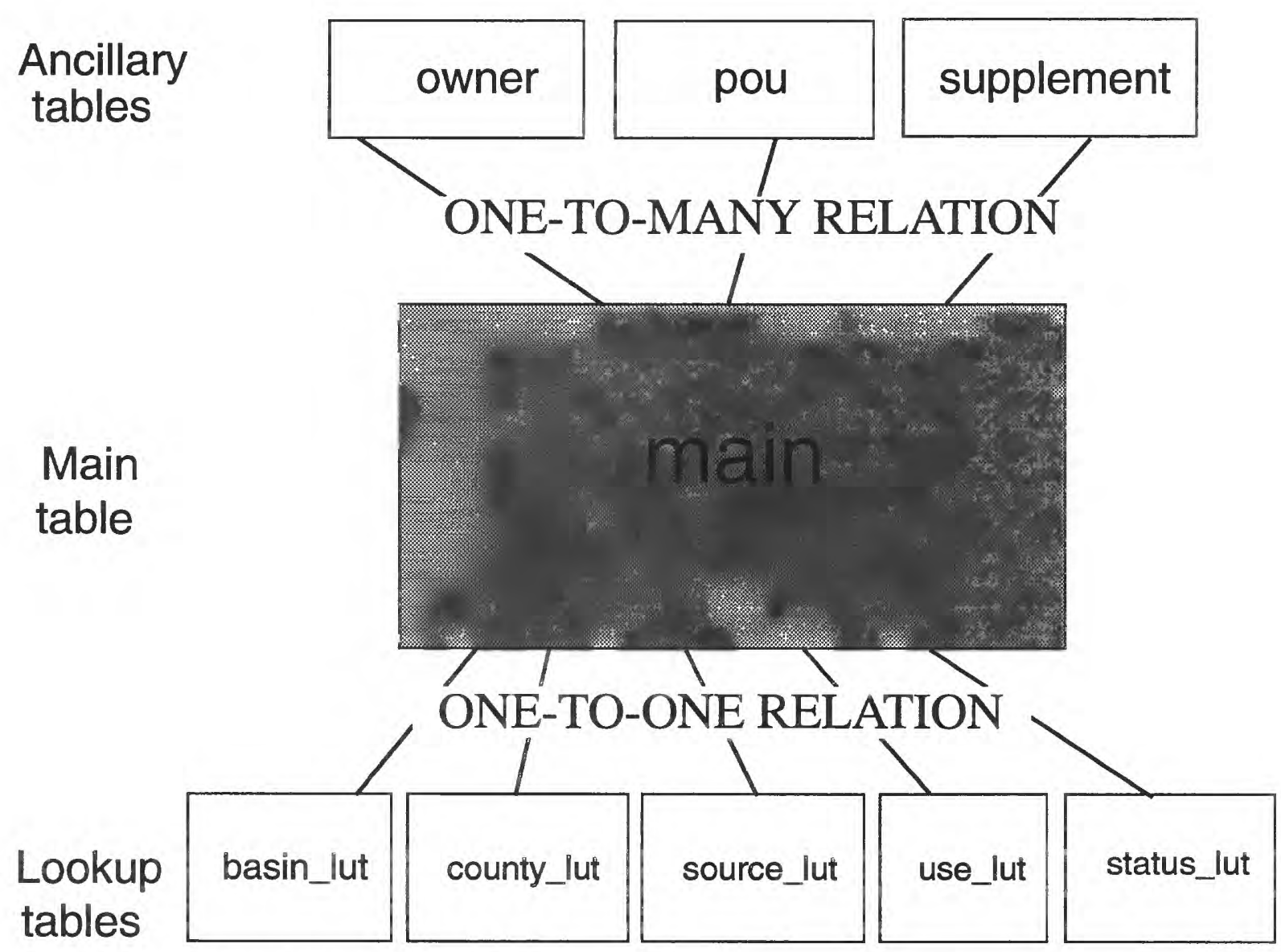

Figure 6. Relations between tables of the permit data base.

The fields in the main table are listed and described in table 2. The fields in the owner, pou, and supplement tables are listed and described in tables 3,4, and 5. A technical description of each field in main, including entry type, width, and template limits is in table 6. A technical description of each field in the ancillary tables, including entry type and width limits, is in tables 7, 8, and 9. A technical description of each field in the lookup tables, including entry type and width limits, is in table 10. County codes and county names are in table 11. Application status codes and descriptions are in table 12. Source codes and descriptions are in table 13. Use codes and descriptions are in table 14. Tables 6-14 are in the appendix. 
Table 2. General description of data fields for main (main) table

[Abbreviations: NDWR, Nevada Division of Water Resources; POD, point of diversion; POU, place of use; MOU, manner of use; PLSS, Public Land Survey System; USGS, U.S. Geological Survey]

\begin{tabular}{|c|c|c|}
\hline Field name & Description & Additional Information \\
\hline APP\# & Application number & $\begin{array}{l}\text { Request for water use (other than domestic or change of } \\
\text { an existing use); number is assigned by NDWR at time } \\
\text { of filing. After all legal requirements have been } \\
\text { satisfied, application may be permitted and } \\
\text { subsequently certified. }\end{array}$ \\
\hline CERT\# & Certificate number & $\begin{array}{l}\text { Assigned by engineering staff at NDWR after permit } \\
\text { terms are satisfied. }\end{array}$ \\
\hline APP_STATUS & Application status & $\begin{array}{l}\text { Current status within NDWR approval process. See } \\
\text { table } 12 \text {. }\end{array}$ \\
\hline BASIN & Basin code & $\begin{array}{l}\text { Based on hydrographic numbering system. See Rush, } \\
1968 .\end{array}$ \\
\hline COUNTY & County code & $\begin{array}{l}\text { Nevada county code for point of diversion (POD). See } \\
\text { table } 11 \text {. }\end{array}$ \\
\hline PREV_APP\# & Previous application number & $\begin{array}{l}\text { If current application changes a previous application, then } \\
\text { entry is for previous application. }\end{array}$ \\
\hline APP_CHANGE & Application change & $\begin{array}{l}\text { Manner in which the previous application (PREV_APP\#) } \\
\text { is being changed. Changes are for any combination of } \\
\text { POD, POU, MOU. }\end{array}$ \\
\hline SOURCE & Water source & Various ground- and surface-water sources. See table 13. \\
\hline SOURCE_DESC & Water source description & Name of well or surface source. \\
\hline USE & Water use & Manner of use. See table 14. \\
\hline PERIOD_START & Period of use, starting date & \\
\hline PERIOD_END & Period of use, ending date & \\
\hline POD_QQ & $\begin{array}{l}\text { Point of diversion, quarter-quarter } \\
\text { section }\end{array}$ & $\begin{array}{l}\text { Location within PLSS quarter-quarter section (40-acre } \\
\text { subdivision). }\end{array}$ \\
\hline POD_Q & Point of diversion, quarter section & $\begin{array}{l}\text { Location within PLSS quarter section (160-acre } \\
\text { subdivision). }\end{array}$ \\
\hline POD_SEC & Point of diversion, section & Location within PLSS section. \\
\hline POD_TWN & Point of diversion, township & Location within PLSS township. \\
\hline POD_RNG & Point of diversion, range & Location within PLSS range. \\
\hline POD_REF & Point of diversion, reference code & $\begin{array}{l}\text { PLSS reference point. Valid codes are: MD, Mount } \\
\text { Diablo; SLC, Salt Lake City; SB, San Bernardino; W, } \\
\text { Willamette; and GSR, Gila and Salt River. }\end{array}$ \\
\hline DUTY & Duty & $\begin{array}{l}\text { Amount of water applied for, in units, specified by duty } \\
\text { units (DUTY_UNITS). }\end{array}$ \\
\hline DUTY_BALANCE & Duty balance & $\begin{array}{l}\text { Duty minus sum of duty entries for permitted change } \\
\text { applications. }\end{array}$ \\
\hline DUTY_UNIT & Duty units code & $\begin{array}{l}\text { Valid codes: AFA, acre-feet/annum; AFS, acre- } \\
\text { feet/season; MGA, million gallons/annum; MGS, } \\
\text { million gallons/season. }\end{array}$ \\
\hline DIV_RATE & Diversion rate & Value stored in cubic feet per second. \\
\hline DIV_BALANCE & Diversion balance & $\begin{array}{l}\text { Diversion rate (DIV_RATE) minus sum of diversion } \\
\text { entries for change applications. }\end{array}$ \\
\hline POU_ACRE_TOTAL & Sum of acreage & Acreage sums for place of use. \\
\hline ACFT_STOR & Storage rate & $\begin{array}{l}\text { Value is annual or seasonal storage in acre-feet, for appli- } \\
\text { cations claiming storage as point of diversion. }\end{array}$ \\
\hline WELL_LOG1 & Well log number 1 & Number assigned by USGS. Well can have multiple logs. \\
\hline WELL_LOG2 & Well log number 2 & Do. \\
\hline WELL_LOG3 & Well log number 3 & Do. \\
\hline
\end{tabular}


Table 2. General descriptions of data fields for main (main) table--Continued

\begin{tabular}{|c|c|c|}
\hline Field name & Description & Additional Information \\
\hline FILE_DT & Filing date & Date application was filed with NDWR. \\
\hline PRIOR_DT & Priority date & $\begin{array}{l}\text { Same as filing date unless application is change } \\
\text { application, or permit is cancelled and then cancellation } \\
\text { subsequently rescinded. Priority date equals filing date } \\
\text { of previous application if change application. }\end{array}$ \\
\hline RTN_DT & Return date & $\begin{array}{l}\text { Date that application is returned to NDWR after } \\
\text { correction by applicant. }\end{array}$ \\
\hline MAP_DT & Map date & $\begin{array}{l}\text { Date that application's supporting map was filed with } \\
\text { NDWR. }\end{array}$ \\
\hline MAP\# & Map number & $\begin{array}{l}\text { Application number stamped on supporting map filed with } \\
\text { NDWR. }\end{array}$ \\
\hline PUB_DT & Publication date & $\begin{array}{l}\text { Date application is sent out for newspaper public notice } \\
\text { publication by NDWR. }\end{array}$ \\
\hline PUB_END_DT & Ending publication date & $\begin{array}{l}\text { Last date of publication, } 4 \text { weeks after publication date } \\
\text { (PUB_DT). }\end{array}$ \\
\hline PROTEST & Protest & $\begin{array}{l}\text { Whether an application was protested. Application may be } \\
\text { protested within } 30 \text { days after publication ending date } \\
\text { (PUB_END_DT). }\end{array}$ \\
\hline FIELD_INV & Field investigation & $\begin{array}{l}\text { Whether a field investigation has been completed by } \\
\text { NDWR. }\end{array}$ \\
\hline DECREE_NAME & Decree name & Adjudicated stream name for vested rights. \\
\hline RFA_DT & Ready for action date & $\begin{array}{l}\text { Date when NDWR will take action on an application, } 30 \\
\text { days after publication ending date (PUB_END_DT). }\end{array}$ \\
\hline WDR_DT & Withdrawn date & Date application was withdrawn by applicant. \\
\hline PER_DT & Permit date & Date application was permitted by NDWR. \\
\hline CAN_DT & Cancellation date & Date permit was cancelled by NDWR. \\
\hline CAN_PORTION & Cancellation of a portion of permit & $\begin{array}{l}\text { A portion, as well as the entire permit, may be cancelled } \\
\text { by NDWR due to noncompliance. }\end{array}$ \\
\hline RUL_DT & Ruling date & Date that NDWR ruled on application or permit. \\
\hline RUL_STATUS & Ruling status & Approved or denied status ruled by NDWR. \\
\hline RUL\# & Ruling number & Ruling prepared by NDWR is assigned a number. \\
\hline RUL_RSN & Ruling reason & Brief description of NDWR final ruling. \\
\hline POC_EXT & $\begin{array}{l}\text { Proof of completion, } \\
\text { extension of time }\end{array}$ & $\begin{array}{l}\text { Whether the applicant has applied for an extension of time } \\
\text { for filing proof of beneficial use. }\end{array}$ \\
\hline POC_DUE_DT & $\begin{array}{l}\text { Proof of completion, } \\
\text { due date }\end{array}$ & $\begin{array}{l}\text { Date the works of diversion must be completed, as } \\
\text { specified in permit terms. }\end{array}$ \\
\hline POC_RCD_DT & $\begin{array}{l}\text { Proof of completion, } \\
\text { received date }\end{array}$ & Date that proof of completion was filed with NDWR. \\
\hline PBU_EXT & $\begin{array}{l}\text { Proof of beneficial use, } \\
\text { extension of time }\end{array}$ & $\begin{array}{l}\text { Whether the applicant applied for an extension of time } \\
\text { with NDWR for filing proof of beneficial use. }\end{array}$ \\
\hline PBU_DUE_DT & $\begin{array}{l}\text { Proof of beneficial use, } \\
\text { due date }\end{array}$ & Final proof of beneficial use required by terms of permit. \\
\hline PBU_RCD_DT & $\begin{array}{l}\text { Proof of beneficial use, } \\
\text { received date }\end{array}$ & Date that proof of beneficial use was received by NDWR. \\
\hline PBU_MAP_DUE & Proof of beneficial use, map due & $\begin{array}{l}\text { Whether a map is required for beneficial use filing by } \\
\text { NDWR. }\end{array}$ \\
\hline PBU_MAP\# & $\begin{array}{l}\text { Proof of beneficial use, } \\
\text { map number }\end{array}$ & $\begin{array}{l}\text { Application number stamped on the supporting map filed } \\
\text { with NDWR. }\end{array}$ \\
\hline PBU_MAP_RCD_DT & $\begin{array}{l}\text { Proof of beneficial use, } \\
\text { map received date }\end{array}$ & Date supporting map was filed with NDWR. \\
\hline CER_DT & Certificate date & Date application was certificated by NDWR. \\
\hline
\end{tabular}


Table 2. General descriptions of data fields for main (main) table--Continued

\begin{tabular}{|c|c|c|}
\hline Field name & Description & Additional Information \\
\hline EXP_DT & Expiration date & $\begin{array}{l}\text { Date temporary or environmental application permit } \\
\text { expires; usually } 1 \text { year after issuance. }\end{array}$ \\
\hline OTHER_DT & Other date & $\begin{array}{l}\text { Reserved for dates associated with rulings for other than } \\
\text { approvals or denials as described by date remark } \\
\text { (DATE_REMARK). }\end{array}$ \\
\hline DATE_REMARK & Date remark & Remarks for date changes or other unique situations. \\
\hline USE_UNITS & Use units & $\begin{array}{l}\text { Brief description of number of units served, such as live- } \\
\text { stock or subdivision lot count. }\end{array}$ \\
\hline REMARK & Remarks & Pertinent remarks about application. \\
\hline REP & Reporting requirement & $\begin{array}{l}\text { Frequency that applicant must report well pumpage data } \\
\text { to NDWR prior to certification. Valid options are } \\
\text { Monthly, Quarterly, Annually. }\end{array}$ \\
\hline SUP_ACRES & Supplemental Acres & Acreage supplemental to ground-water permit. \\
\hline SUP_ACRE_FT & Supplemental Acre-foot & Duty associated with supplemental-acres (SUP_ACRES). \\
\hline SUP_SRC & Supplemental source & Source of supplemental acres. \\
\hline SUB_BASIN & Sub-basin code & $\begin{array}{l}\text { Internal NDWR code that further subdivides basin code } \\
\text { (BASIN). }\end{array}$ \\
\hline SUP_ADJ & Supplemental adjustment & Optional duty adjustment to ground-water permit. \\
\hline
\end{tabular}

Table 3. General description of data fields for owner (owner) table

\begin{tabular}{|l|l|l|}
\hline \multicolumn{1}{|c|}{ Field name } & \multicolumn{1}{|c|}{ Description } & \multicolumn{1}{c|}{ Additional information } \\
\hline \hline APP\# & Application number & $\begin{array}{l}\text { Request for water use (other than domestic or change of an existing } \\
\text { use); number is assigned by NDWR at time of filing. After all legal } \\
\text { requirements have been satisfied, application may be permitted and } \\
\text { subsequently certified. }\end{array}$ \\
\hline OWNER_NAME & Owner name & Application may have multiple owners. \\
\hline OWNER_TYPE & Owner type & $\begin{array}{l}\text { Whether the specified owner is the original owner, current owner, or } \\
\text { both }\end{array}$ \\
\hline OWNER_PCT & Percent of ownership & Percent of permit owned by specified owner \\
\hline OWNER_DUTY & Duty & Portion of duty owned by specified owner \\
\hline OWNER_DIV_RATE & Diversion rate & Portion of diversion rate owned by specified owner \\
\hline
\end{tabular}

Table 4. General descriptions of data fields for place of use (pou) table

\begin{tabular}{|l|l|l|}
\hline Field name & \multicolumn{1}{|c|}{ Description } & \multicolumn{1}{c|}{ Additional information } \\
\hline \hline APP\# & Application number & $\begin{array}{c}\text { Request for water use (other than domestic or change of an existing } \\
\text { use); number is assigned by NDWR at time of filing. After all } \\
\text { legal requirements have been satisfied, application may be } \\
\text { permitted and subsequently certified. }\end{array}$ \\
\hline POU_QQ & Place of use, quarter-quarter section & Location within PLSS quarter-quarter section (40- acre subdivision) \\
\hline POU_Q & Place of use, quarter section & Location within PLSS quarter section (160-acre subdivision) \\
\hline POU_SEC & Place of use, section & Location within PLSS section \\
\hline POU_TWN & Place of use, township & Location within PLSS township \\
\hline POU_RNG & Place of use, range & Location within PLSS range \\
\hline POU_REF & Place of use, reference & $\begin{array}{l}\text { PLSS refernce point. Valid codes: MD, Mount Diablo; SLC, Salt } \\
\text { Lake City; SB, San Bernardino; W, Willamette; GSR, Gila and } \\
\text { Salt River }\end{array}$ \\
\hline POU_ACRE & Place of use, acres & Number of acres within place of use \\
\hline
\end{tabular}


Table 5. General descriptions of data fields for supplemental (supplement) table

\begin{tabular}{|l|l|l|}
\hline Field name & \multicolumn{1}{|c|}{ Description } & \multicolumn{1}{c|}{ Additional Information } \\
\hline \hline APP\# & Application number & $\begin{array}{c}\text { Request for water use (other than domestic or change of an existing } \\
\text { use); number is assigned by NDWR at time of filing. After all } \\
\text { legal requirements have been satisfied, application may be } \\
\text { permitted and subsequently certified. }\end{array}$ \\
\hline SUP_APP\# & Supplemental application number & $\begin{array}{l}\text { Application(s) supplemental to current application. Supplemental } \\
\text { applications are identified by NDWR at issuance of permit. }\end{array}$ \\
\hline SUP_AMT & Supplemental duty amount & $\begin{array}{c}\text { Adjustment value that assures total supplemental duties equal duty } \\
\text { allowed under condition of permits. Adjustment value is manually } \\
\text { entered by users with access level 1. }\end{array}$ \\
\hline
\end{tabular}

\section{Reports}

Users with access levels one and two may invoke several reports for retrieving and organizing the water-permit data. The reports can identify adjacent and potentially conflicting water-rights applications and summarize water-right information. Seven reports currently are available: (1) “APPLICATION DUE - TICKLER REPORT” notifies managers of pending legal dates, on the basis of the application status; (2) "CHECK REPORT" summarizes the previous . day's, or range of day's activity; (3) "NEW APPLICATIONS FOR MONTH" summarizes the previous month's activities; (4) "HYDROGRAPHIC BASIN ABSTRACT" summarizes groundwater information by hydrographic basin; (5) "SPECIAL HYDROGRAPHIC ABSTRACT" summarizes ground-water information for any user-specified combination of source, status, and several other fields; (6) "POSSIBLE SUPPLEMENTAL REPORT" notifies managers of potentially conflicting claims; and (7) “ABROGATION HISTORY TREE REPORT" lists the abrogation history for a specified report. Reports can be viewed on the screen or sent to a printer.

\section{Interface Screens}

The user, depending upon access level, performs data queries, appends, and updates through a series of interface screens. The main menu for each access level displays the set of menu options available to the user (see figs. 1-5).

\section{Data-Query Menu Options}

A data query retrieves water-permit data without updating the data. A query can be made by using three menu options:

Option A1 - Retrieve by application number (APP\#). Option A1 retrieves water-rights data by the water-rights application number. When query by application number (A1) is selected from the main menu, a small pop-up menu prompts the user for an application number. After the user has entered the desired application number and moved out of the application number entry field, the screen clears and the first page of permit information appears on the screen.

Option A2 - Retrieve by certificate number (CERT\#). Option A2 retrieves water rights data by the certificate number and displays the same information as described for Option A1. When query by certificate number (A2) is selected, the user is prompted for a certificate number.

Option A3 - Retrieve by owner name (OWNER_NAME). Option A3 first retrieves all owner names that match a specified name and then retrieves the same information as described for Option A1. When query by owner name (A3) is selected, the user is prompted for an owner name and search method, either binary or sequential. Binary 
search allows fast retrieval but does not permit internal matches (searching for a string within a character string). Sequential search is much slower but allows internal matches. A list of owner names matching a user-specified name is written to the screen, along with associated data fields (owner status; application number; application status; source; point of diversion information using locations based on the township, range, section, quarter, quarter-quarter of the public land survey system (PLSS); basin; and use). The user is prompted to select one application record from the list.

\section{Data-Append Menu Option}

Data append is used to add new records to the data base. Data append uses the following option:

Option B1 - Append new information to the data base. Option B1 allows the user to input a new water-rights application and begin data entry.

\section{Data-Update Menu Option}

Data update is used to correct or update an existing record. Data can be updated using the following option:

Option B2 - Update previously entered information for an application. Option B2 allows the user to retrieve a water-rights record and then update the information.

\section{Data-Report Menu Options}

The data, retrieved by either the Query, Append, or Update option, are displayed on a series of five screen pages. These screens are shown in figures 7-11. The interface screens guide the user through the data available for a specific application number. A description of each field associated with the application is in table 2. Reports are accessed by the following menu options:

Option C1 - "APPLICATION(S) DUE-TICKLER REPORT." The "APPLICATION(S) DUETICKLER REPORT" column headings are shown in figure 12. The report has the following characteristics:

- Report is generated the first workday of each week.

- Records are sorted by due date then by application number (APP\#).

- Report includes all current owners for a given application number.

- Report prints '*** NO FILES DUE FOR THIS PERIOD ***' if no matches are found for a given application status (APP_STATUS)

- Report includes four sections, one for each of the following date fields:

RFA - Ready for Action (RFA_DT field)

RFC - Return for Corrections due (RTN_DT field)

POC - Proof of Completion due (POC_DUE_DT field)

PBU - Proof of Beneficial Use due (PBU_DUE_DT field)

- Records are included in report if period of 60 days after return date (RTN_DT+ 60 days) matches any day in the current week (Monday through Sunday) for the RFC section. 
Option C2 - "CHECK REPORT - NEW APPLICATIONS." The "CHECK REPORT - NEW APPLICATIONS" column headings are shown in figure 13. The report has the following characteristics:

- Report is generated for a specified filing-date range (FILE_DT).

- Records are sorted by application number (APP\#).

- Records are included in the report if a modification was made since the last report.

- Report gives the option of listing either the first or all current owners.

- " ${ }^{~} \mathrm{CHG}$ " column indicates whether application is a Change Application, (changes an earlier application).

- Report prints source name if water source is ground water (SOURCE equals UG, GEO, or OGW); otherwise source description prints in the "SOURCE" column.

- Records for secondary applications are printed as a group at the end of report.

Option C3 - "MONTHLY WATER LOG REPORT." The "MONTHLY WATER LOG REPORT" column headings are shown in figure 14 . The report has the following characteristics:

- Report is generated for a user-specified month.

- Records are sorted by application number (APP\#).

- Records are included in the report if a modification was made during the specified month.

- Report gives the option of listing either the first or all current owners.

- "DATE" column lists the application filing date field (FILE_DT).

- "CHG" column indicates whether application is a Change Application (changes an earlier application).

- Report prints source name if water source is ground-water (SOURCE equals UG, GEO, or OGW); otherwise source description prints in the "SOURCE" column.

- Records for secondary applications are printed as a group at the end of report.

Option C4 - "HYDROGRAPHIC BASIN ABSTRACT/SUMMARY." The "HYDROGRAPHIC BASIN ABSTRACT/SUMMARY" column headings are shown in figure15. The report contains the following three sections by hydrographic basin.

1. Hydrographic Basin Abstract-Lists information on ground-water sources for any status (APP_STATUS). Output records are sorted by application number (APP\#) in ascending order.

2. Hydrographic Basin Groundwater by status for active ground-water sourcesSummarizes supplementally adjusted annual duty for ground-water sources (SOURCE equals UG, GEO, or OGW) by status (APP_STATUS).

3. Hydrographic Basin Summary by manner of use for ground-water sourcesSummarizes active and pending annual duties by manner of use (USE). Report includes supplementally adjusted duties and duties associated with applications to change. 
The report has the following characteristics:

- Report is generated for a user-specified basin number (BASIN).

- Records are sorted by application number (APP\#), then change of application number (PREV_APP\#).

- Records are included in the report for ground-water sources (SOURCE equals UG, GEO, or OGW) and active status (APP_STATUS equals APP, RFA, RFP, PER, CER, DEC, RVK, VST, RES, or RLP).

- "CHANGE OF APP\# "column indicates previous applications and all abrogating applications. Abrogating applications are flagged with CHANGE BY.

- "SUP" column indicates whether application has a supplemental application.

Option C5 - "SPECIAL HYDROGRAPHIC ABSTRACT." The "SPECIAL HYDROGRAPHIC ABSTRACT" allows the user to specify one or more data criteria by which to retrieve information. The input screen for entering user-specified criteria is shown in figure 16. The column headings from the resulting reports are shown in figure 17. The reports have the following characteristics:

- Report is generated from user-specified criteria for any combination of basin (BASIN), township (POD-TWN), range (POD_RNG), section (POD_SEC), application status (APP_STATUS), source (SOURCE), use (USE), owner (OWNER_NAME), and start and end filing date (FILE_DT).

- Records are sorted by application number (APP\#), then change of application number (PREV_APP\#).

- “CHANGE OF APP\#” column indicates previous applications (PREV_APP\#) and abrogating applications (APP_CHANGE). Abrogating applications are flagged with CHANGE BY.

- "SUP" column indicates whether application has a supplemental application.

Option C6 - "POSSIBLE SUPPLEMENTAL REPORT." The "POSSIBLE SUPPLEMENTAL REPORT" column headings are shown in figure 18. The report has the following characteristics:

- Report is generated for a user-specified basin number (BASIN).

- Records are included in report for ground-water sources (SOURCE equals UG, GEO, or OGW) and active status (APP_STATUS equals PER, CER,VST, or $\mathrm{DEC})$.

- Records are sorted and grouped by place of use (POU) field. Within POU fields, records are sorted by application number (APP\#).

Option C7 - "ABROGATION HISTORY TREE." Abrogation history tree shows the sequence of abrogations for a user-specified permit number using a tree diagram. The tree diagram shows historical changes leading up to a user-specified permit number. The column headings from the report are shown in figure 19. 


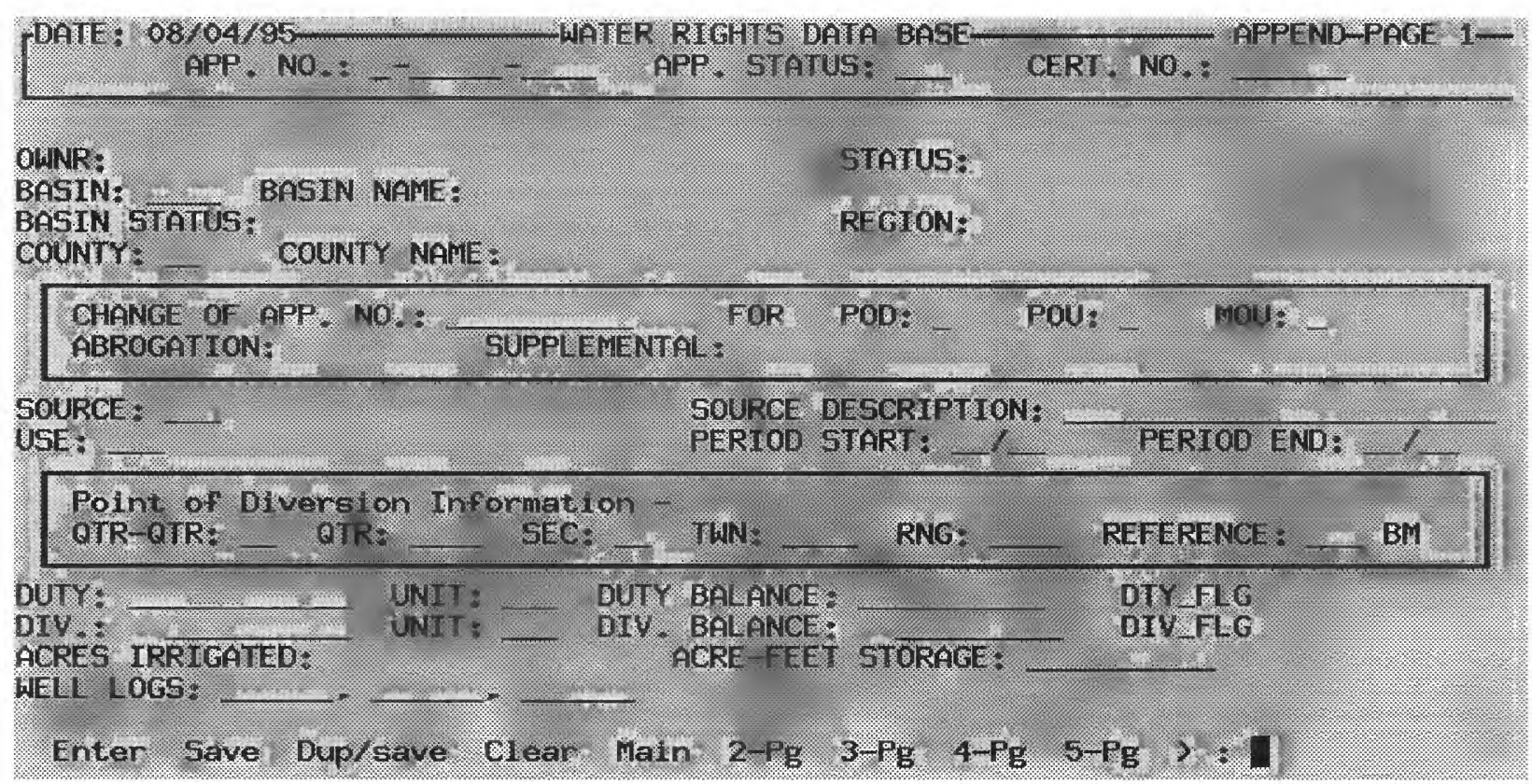

Figure 7. Page one for append mode. Screen is similar when in update or query mode.

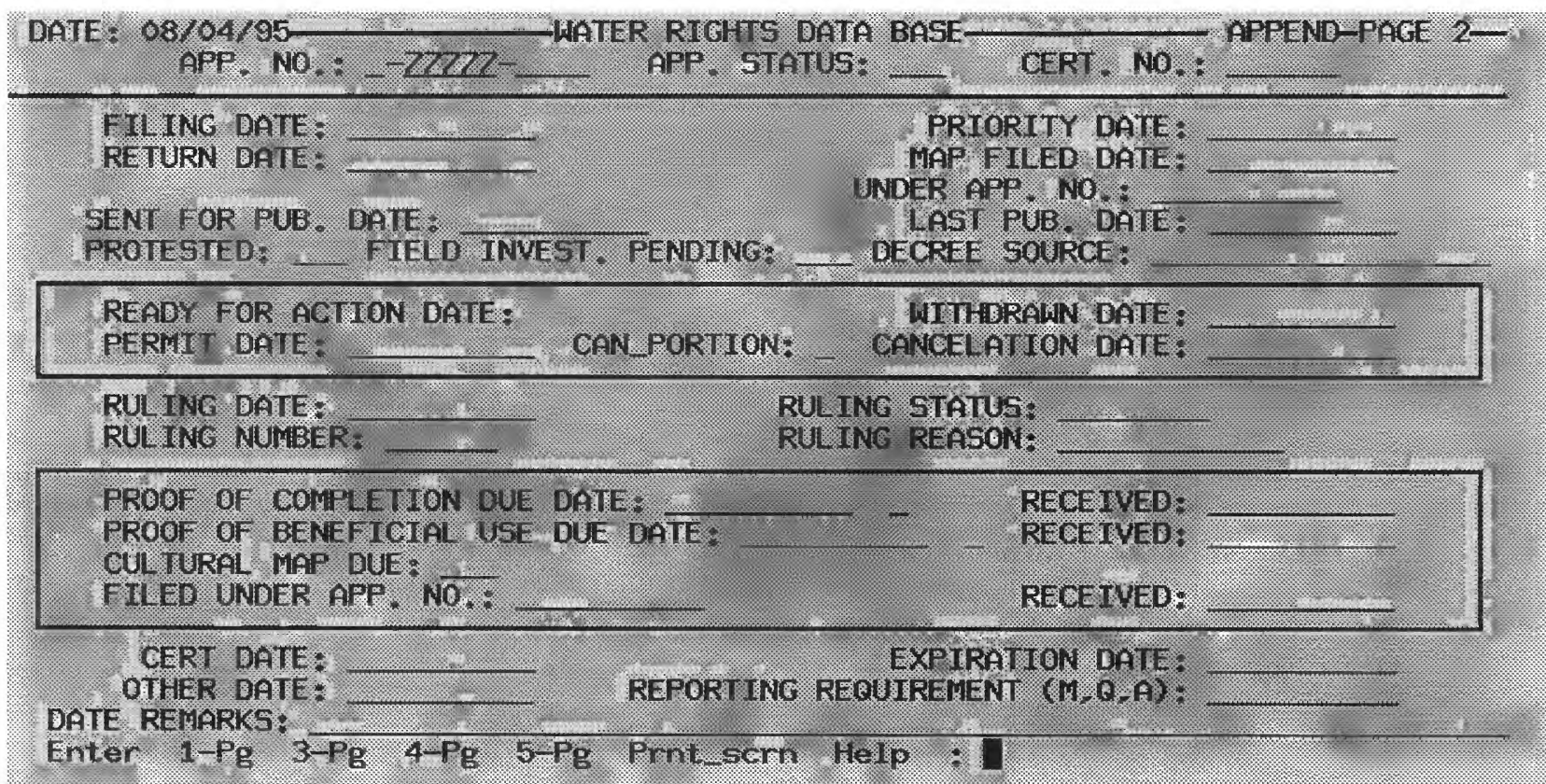

Figure 8. Page two for append mode. Screen is similar when in update or query modes. 


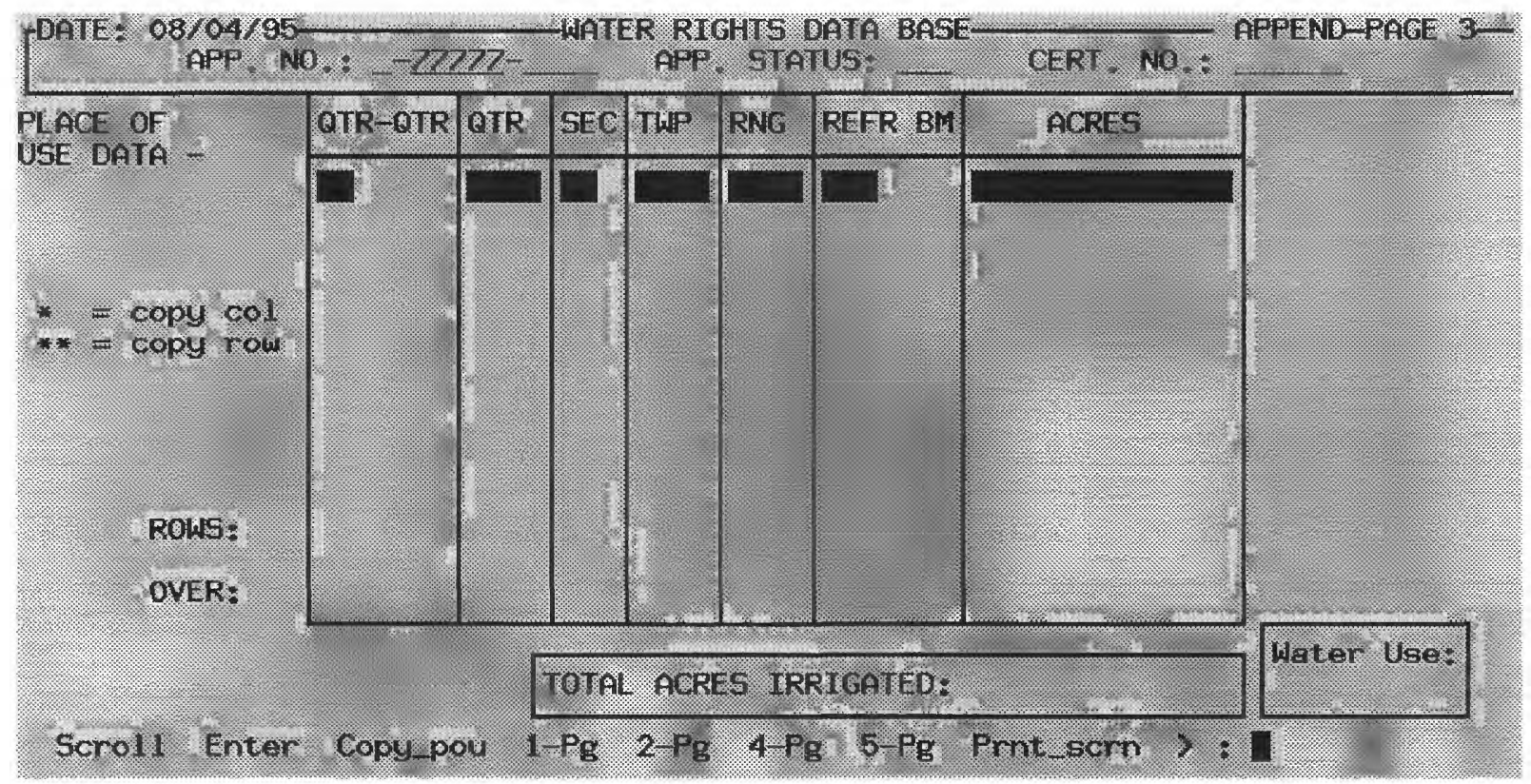

Figure 9. Page three for append mode. Screen is similar when in update or query modes.

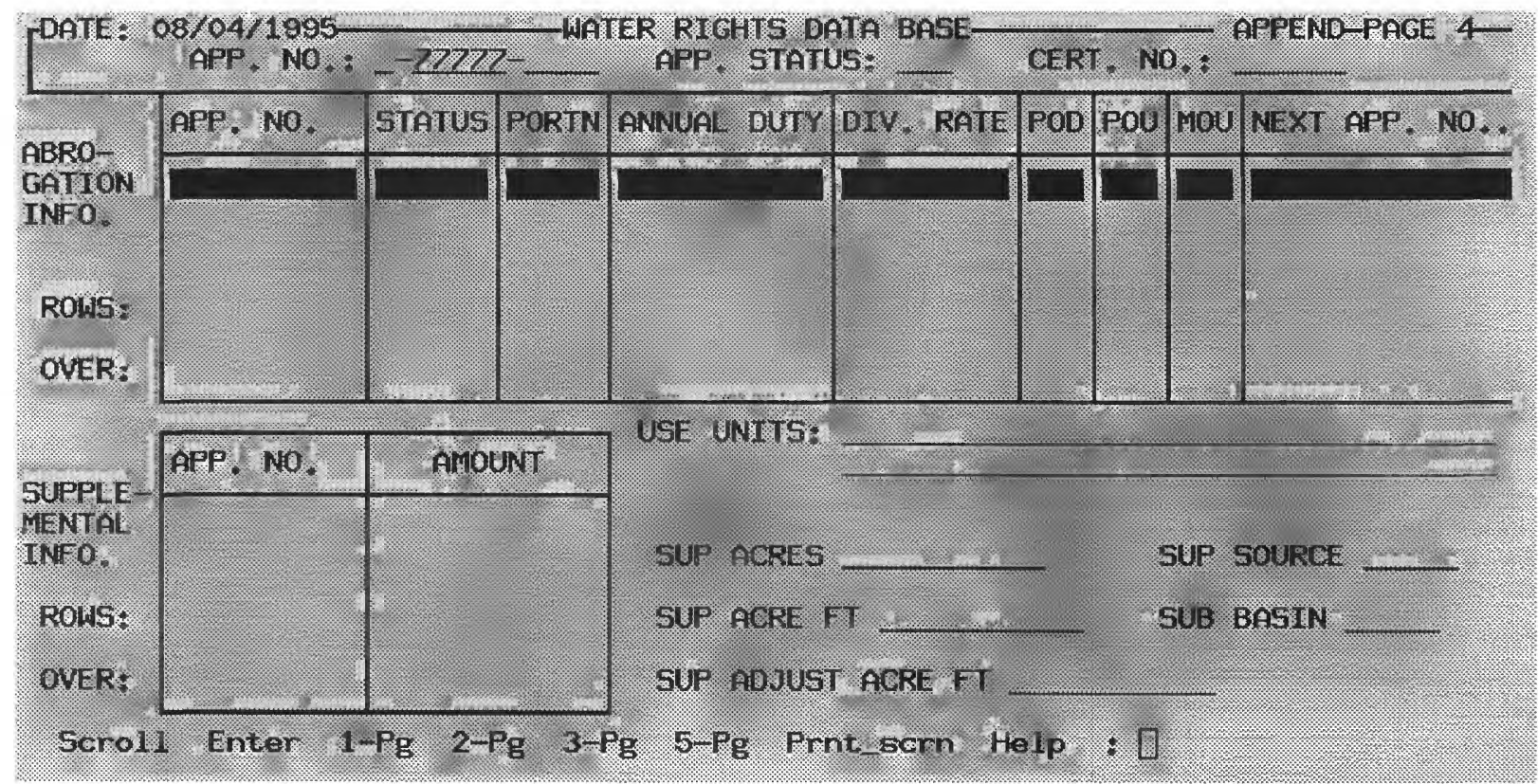

Figure 10. Page four for append mode. Screen is similar when in update or query modes. 


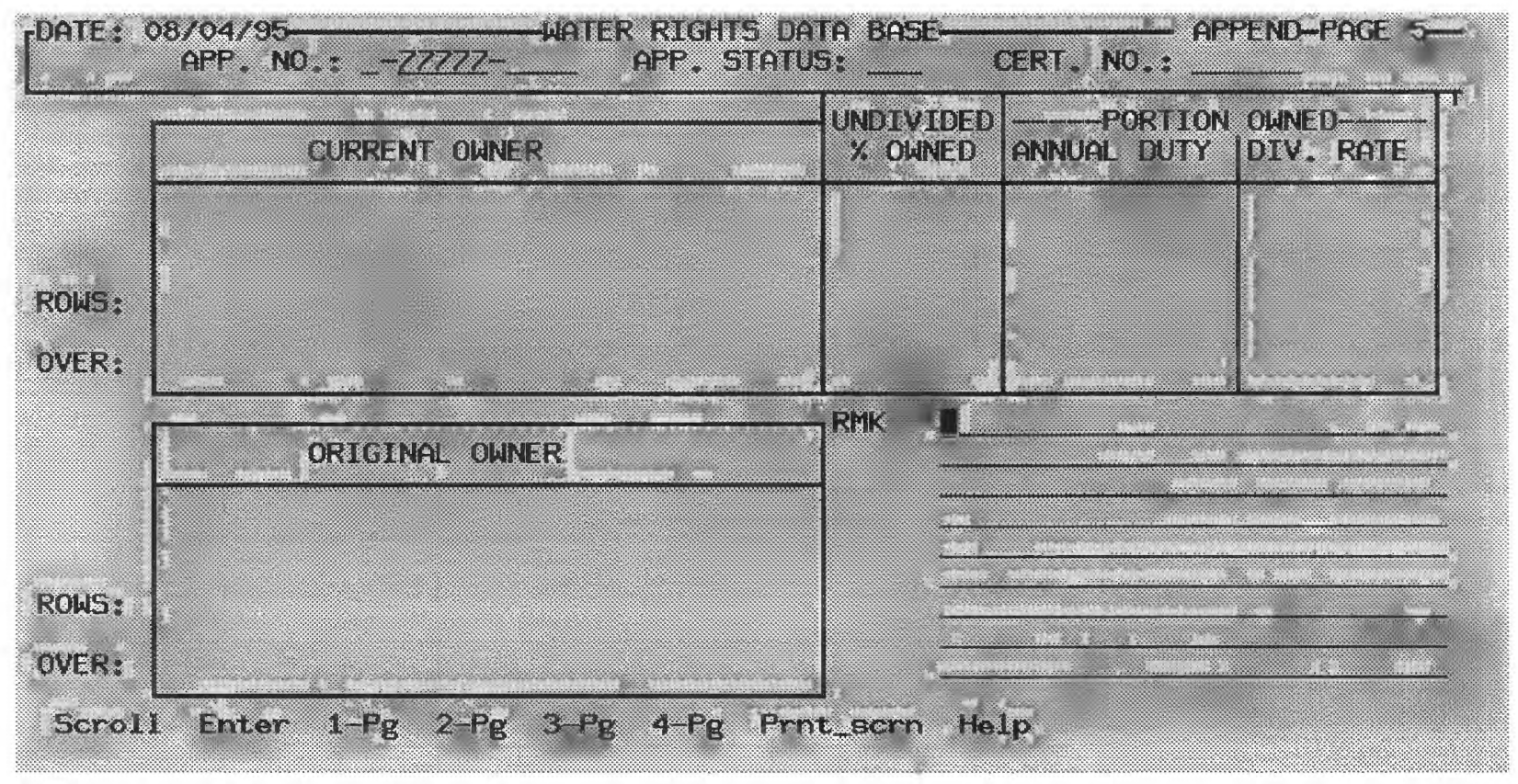

Figure 11. Page five for append mode. Screen is similar when in update or query modes. 

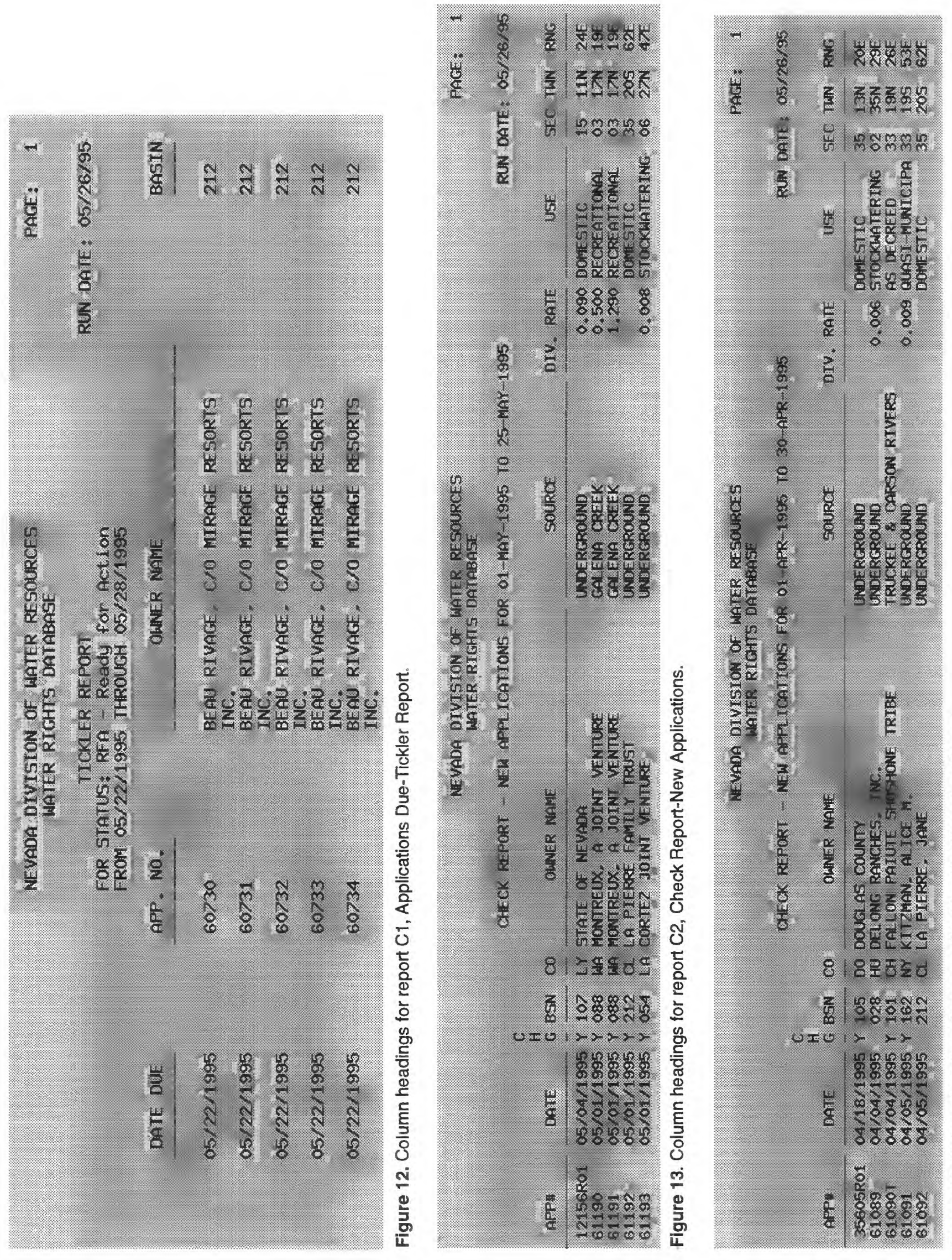

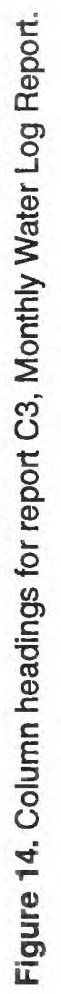




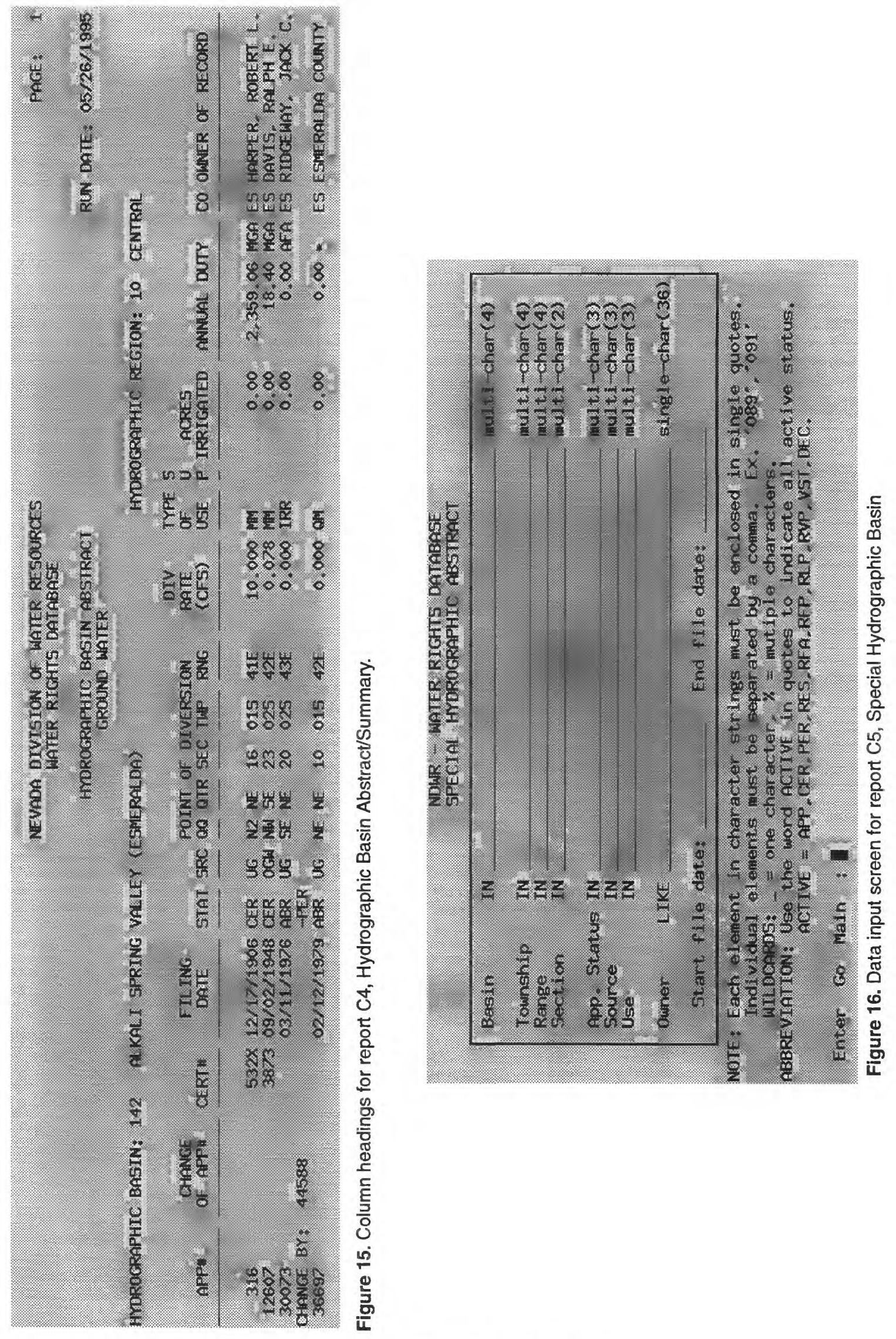



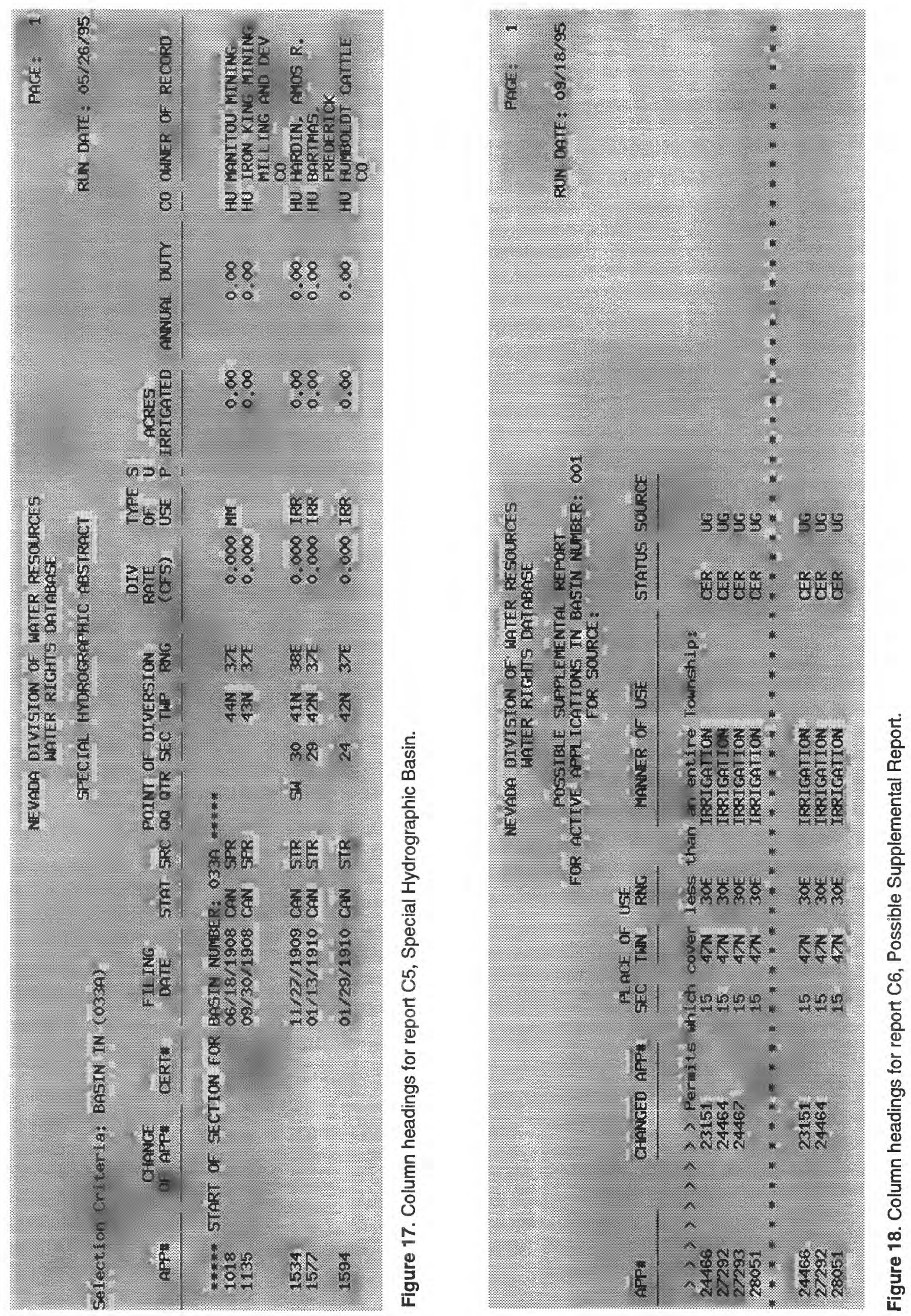


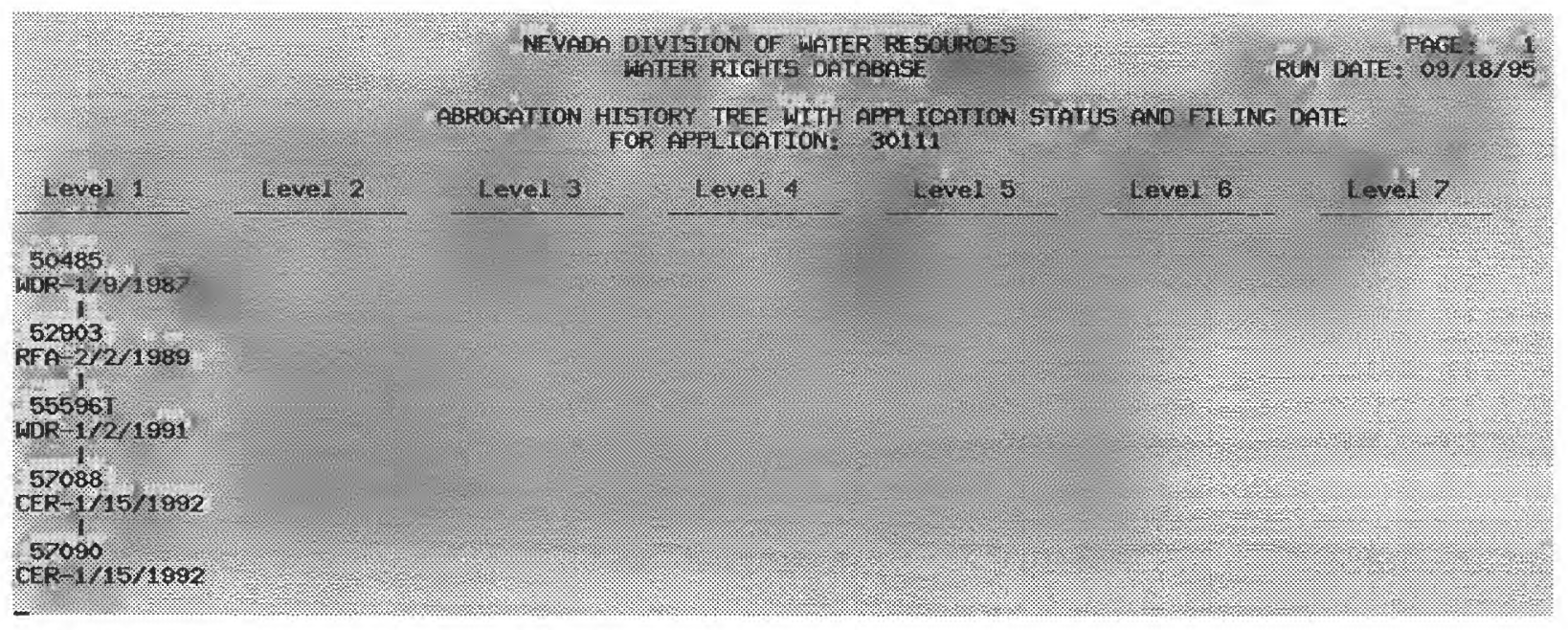

Figure 19. Column headings for report C7, Abrogation History Tree.

\section{REFERENCES CITED}

Nevada Division of Water Planning, 1994, Water words dictionary: Nevada Department of Conservation and Natural Resources, $137 \mathrm{p}$.

Nevada Division of Water Resources, 1993, Nevada water laws-Title 48, Water: Nevada Department of Conservation and Natural Resources, unpaginated.

-1994, Summary of statutory procedure in making application for a water right and filing proofs of appropriation and fees set by statute: Nevada Department of Conservation and Natural Resources, $15 \mathrm{p}$.

Nevada State Engineer's Office, 1974, Water for Nevada-Water planning report: Nevada Department of Conservation and Natural Resources, $60 \mathrm{p}$.

Rush, F.E., 1968, Index of hydrographic areas in Nevada: Nevada Division of Water Resources, Information Report 6, 38 p. 


\section{APPENDIX}




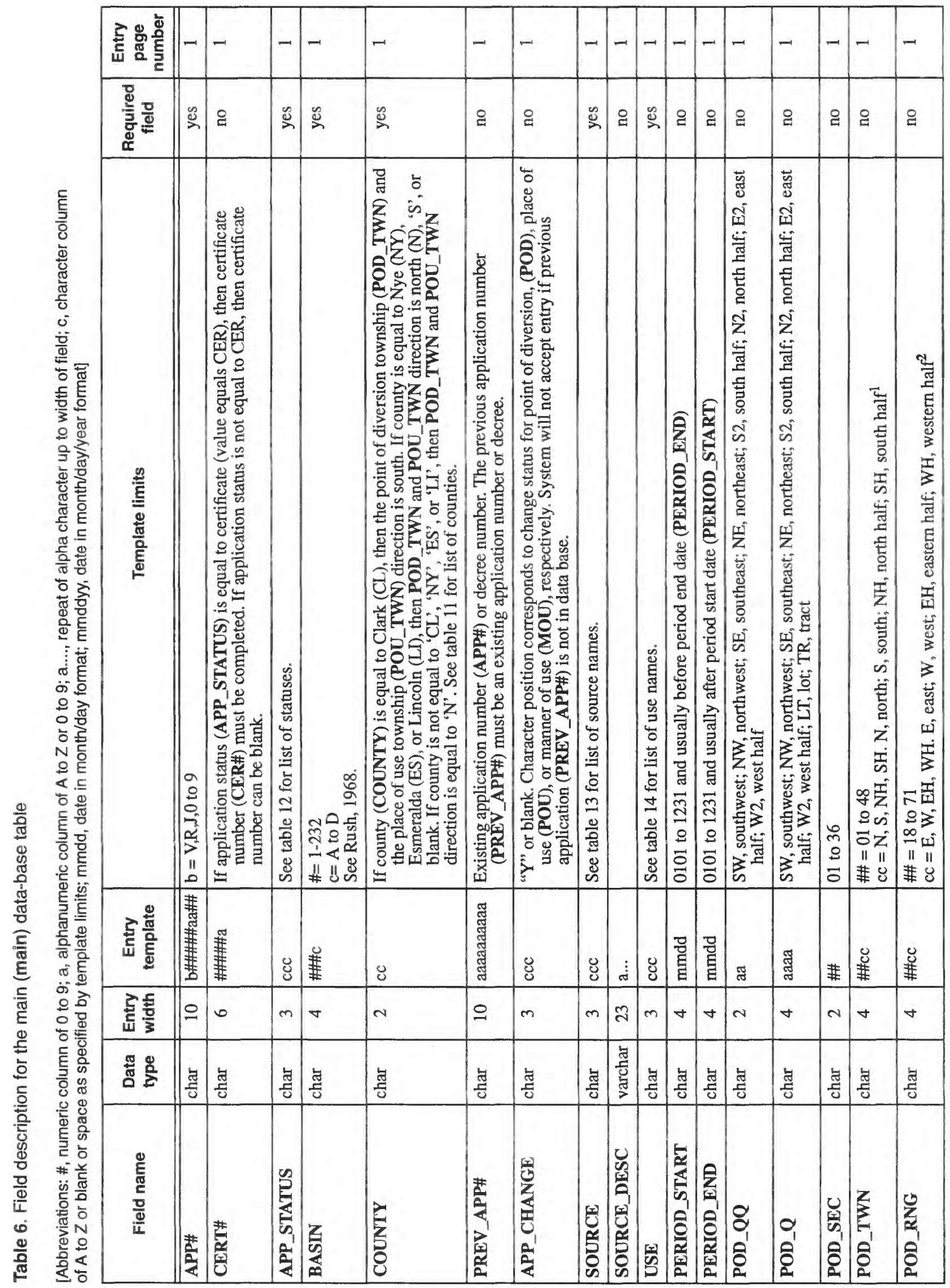




\begin{tabular}{|c|c|c|c|c|c|c|c|c|c|c|c|c|c|c|c|c|c|c|c|c|c|c|}
\hline 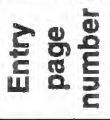 & - & - & - & - & -1 & -1 & - & -1 & - & -1 & - & $N$ & $\sim$ & $N$ & $\sim$ & $N$ & $N$ & $N$ & $N$ & $\sim$ & $N$ & $N$ \\
\hline 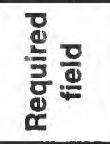 & \& & ‡ & \& & $\stackrel{\infty}{2}$ & 음 & 움 & ‡ & \& & \& & 올 & & $\stackrel{\infty}{2}$ & $\stackrel{\mathscr{\nu}}{\sim}$ & 옴 & ㅇ & 울 & 을 & 올 & ㅇ & 일 & 음 & ‡ \\
\hline 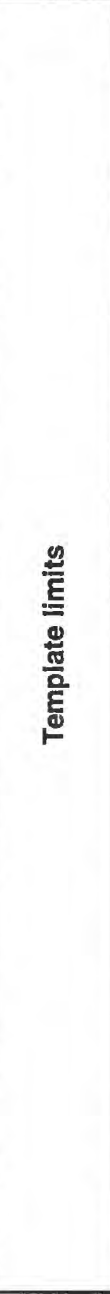 & 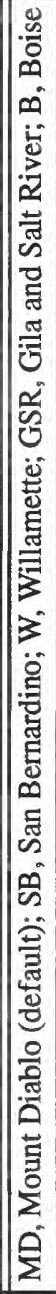 & & & 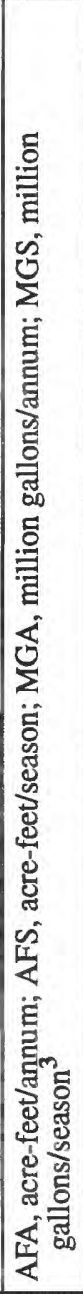 & & & 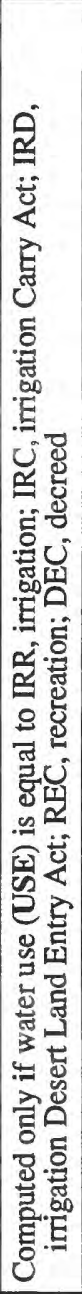 & & & & & 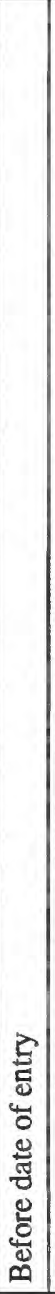 & 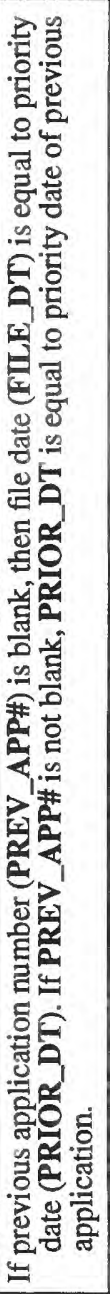 & 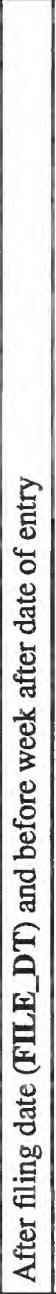 & 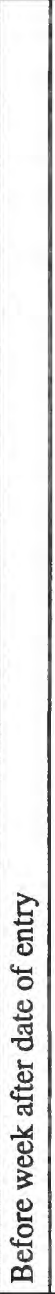 & & 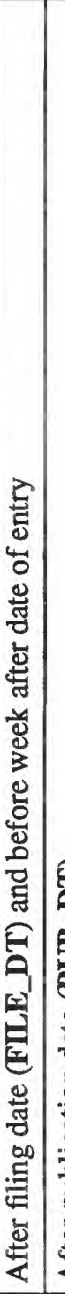 & 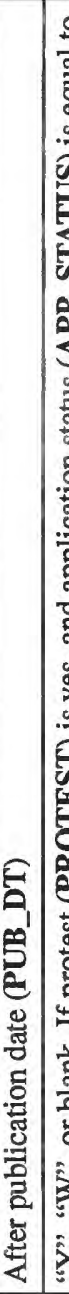 & 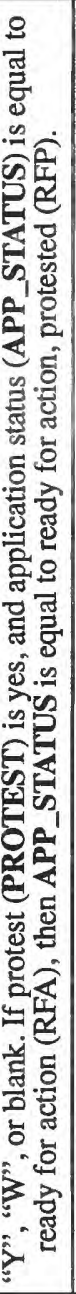 & 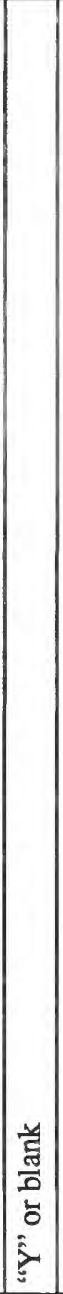 & & 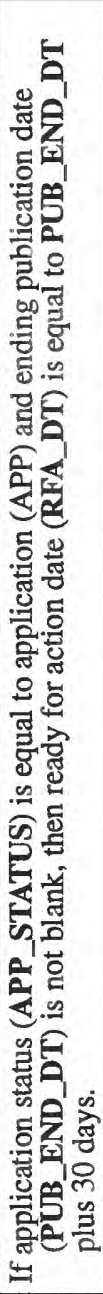 \\
\hline 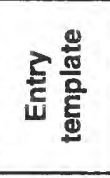 & छ & 華 & 華 & ¿ & 華 & \begin{tabular}{|l} 
茟 \\
華 \\
\end{tabular} & 華 & $\begin{array}{l}\text { 華 } \\
\text { 華 } \\
\text { 健 } \\
\end{array}$ & 華 & 建 & 華 & 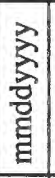 & 交 & 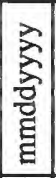 & $\begin{array}{l}\text { 交 } \\
\text { 吾 } \\
\text { 蒠 }\end{array}$ & $\begin{array}{l}\text { 莍 } \\
\text { 建 } \\
\text { 建 } \\
\end{array}$ & 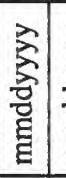 & 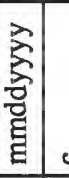 & 0 & 0 & $\dot{0}$ & 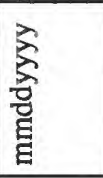 \\
\hline 总咅 & $m$ & $a$ & $a$ & $m$ & $\infty$ & $\infty$ & a & $a$ & 0 & 0 & 0 & $\leqslant$ & $\$$ & 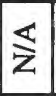 & $\$$ & 이 & 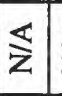 & 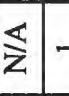 & - & - & $\infty$ & $\$$ \\
\hline 宽足 & 흘 & 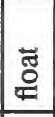 & 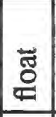 & 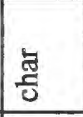 & \begin{tabular}{|l|}
\multirow{g}{*}{} \\
\end{tabular} & 岕 & 氶 & 蒫 & 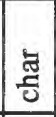 & 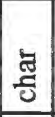 & 氶 & 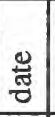 & 苞 & 苛 & 总 & ్ㅠㅁ & 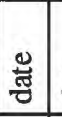 & 苋 & 콩 & 흉 & 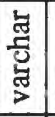 & 苂 \\
\hline 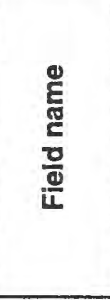 & 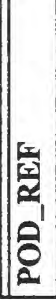 & 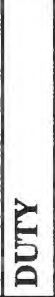 & 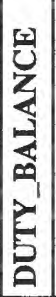 & 罟 & 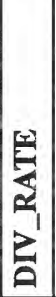 & 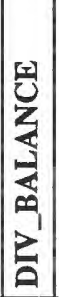 & 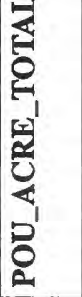 & 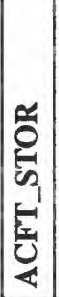 & 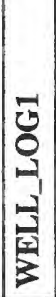 & 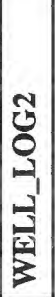 & 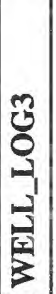 & 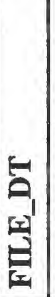 & 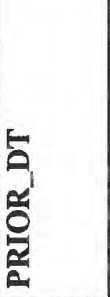 & 旨 & 旨 & $\sum_{\Sigma}$ & 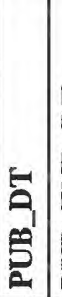 & 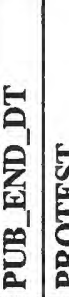 & 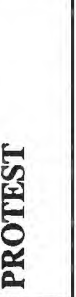 & 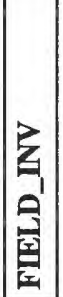 & 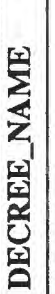 & $\frac{5}{2}$ \\
\hline
\end{tabular}




\begin{tabular}{|c|c|c|c|c|c|c|c|c|c|c|c|c|c|c|c|c|c|c|c|c|}
\hline 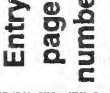 & $N$ & $N$ & $N$ & $N$ & $N$ & $N$ & $\sim$ & $\sim$ & $N$ & $\sim$ & $N$ & $\sim$ & $N$ & $N$ & $N$ & $N$ & $N$ & $N$ & $N$ & $N$ \\
\hline 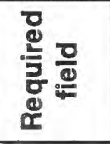 & 욤 & $\because$ & & \& & $\stackrel{9}{\dddot{2}}$ & & \& & \& & \& & 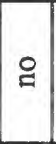 & 잉 & \& & 이 & \& & 울 & ๕ & 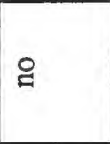 & ‡ & ญे & 요 \\
\hline 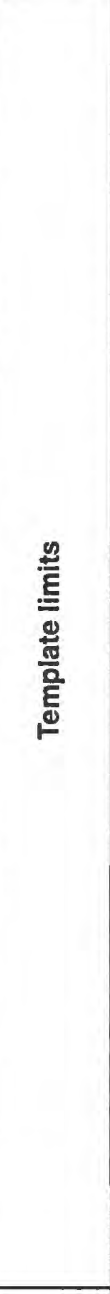 & 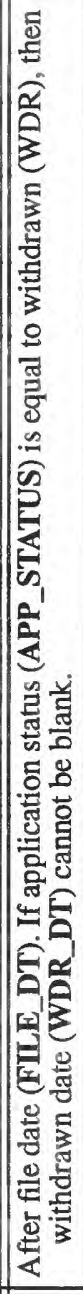 & 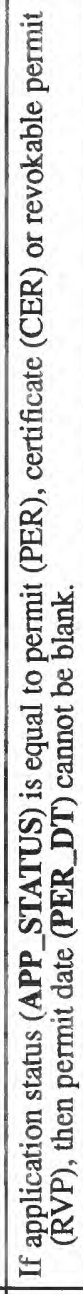 & 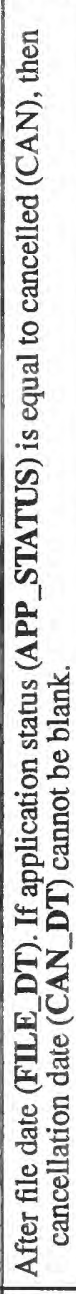 & 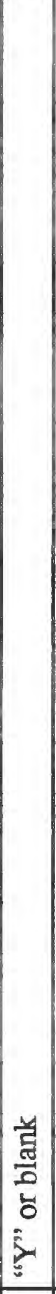 & 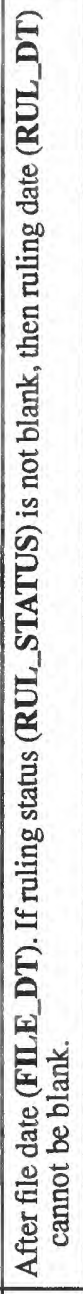 & 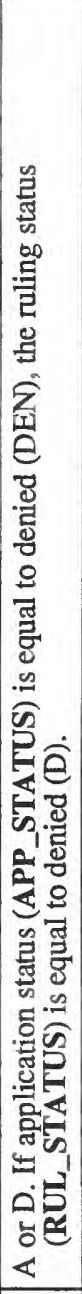 & & & 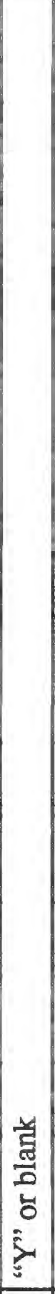 & 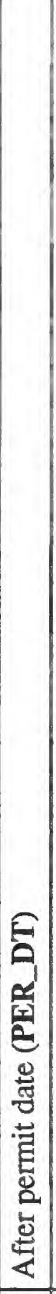 & 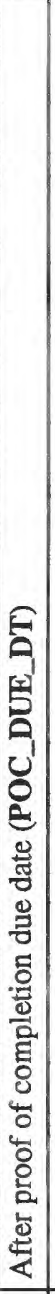 & 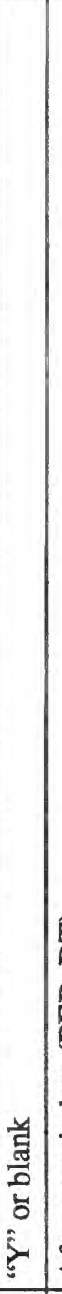 & 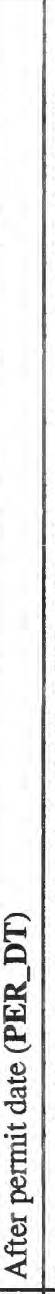 & 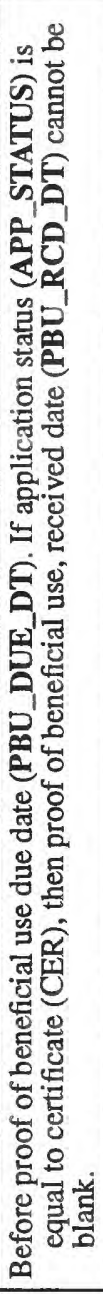 & 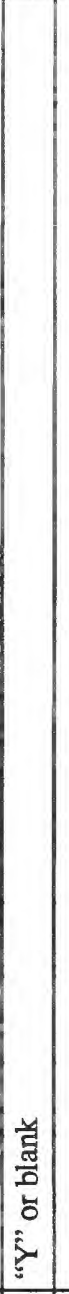 & & 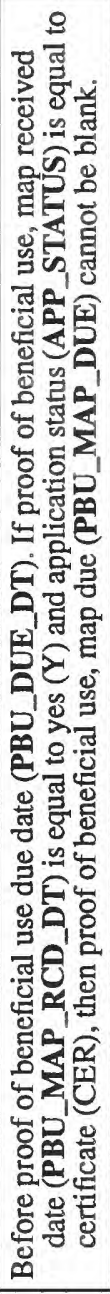 & 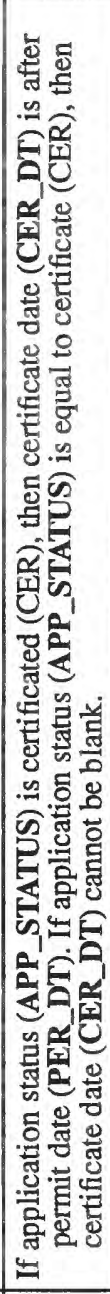 & 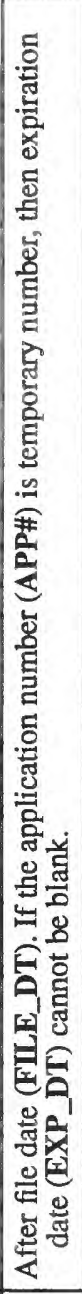 & \\
\hline 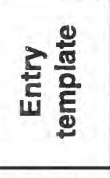 & 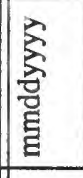 & $\begin{array}{l}\text { 令 } \\
\text { 鸪 } \\
\text { E }\end{array}$ & $\begin{array}{l}\text { 㫘 } \\
\text { 吾 } \\
\text { 音 }\end{array}$ & 0 & 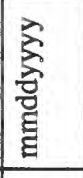 & 0 & 建 & ڤ్ర & 0 & 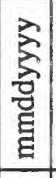 & $\begin{array}{l}\text { 客 } \\
\text { 吾 } \\
\text { 晋 }\end{array}$ & & 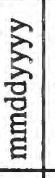 & 疍 & 0 & 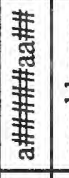 & 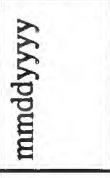 & 趁 & 趁 & 趁 \\
\hline 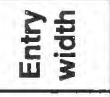 & 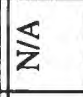 & $\ll$ & $\frac{\mathbb{Z}}{\mathrm{z}}$ & -1 & $\leqslant$ & - & 0 & $\simeq$ & - & $\$$ & $\frac{\$}{z}$ & - & $\$$ & $\leqslant$ & -1 & 이 & 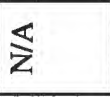 & $\leqslant$ & $\overleftarrow{z}$ & 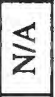 \\
\hline 要 & 苟 & 䒕 & 苛 & 휼 & 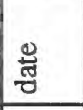 & 苞 & 氶 & 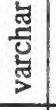 & ㅎّㅇ & 䒕 & 总 & 密. & 岜 & 苋 & 总 & 总 & ग्ّँ & 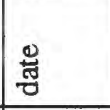 & 总 & 莺 \\
\hline 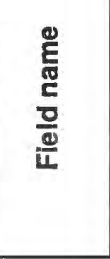 & 垈 & 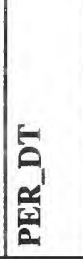 & 占 & 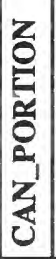 & 照 & 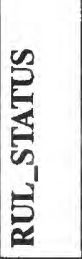 & 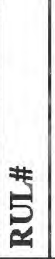 & 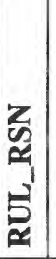 & 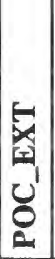 & 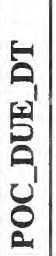 & 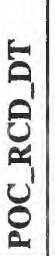 & 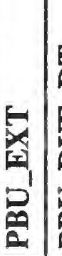 & 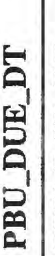 & 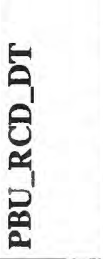 & 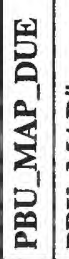 & 巷 & 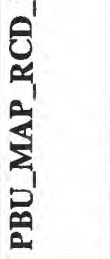 & 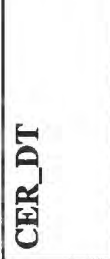 & 占 & 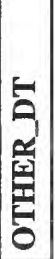 \\
\hline
\end{tabular}



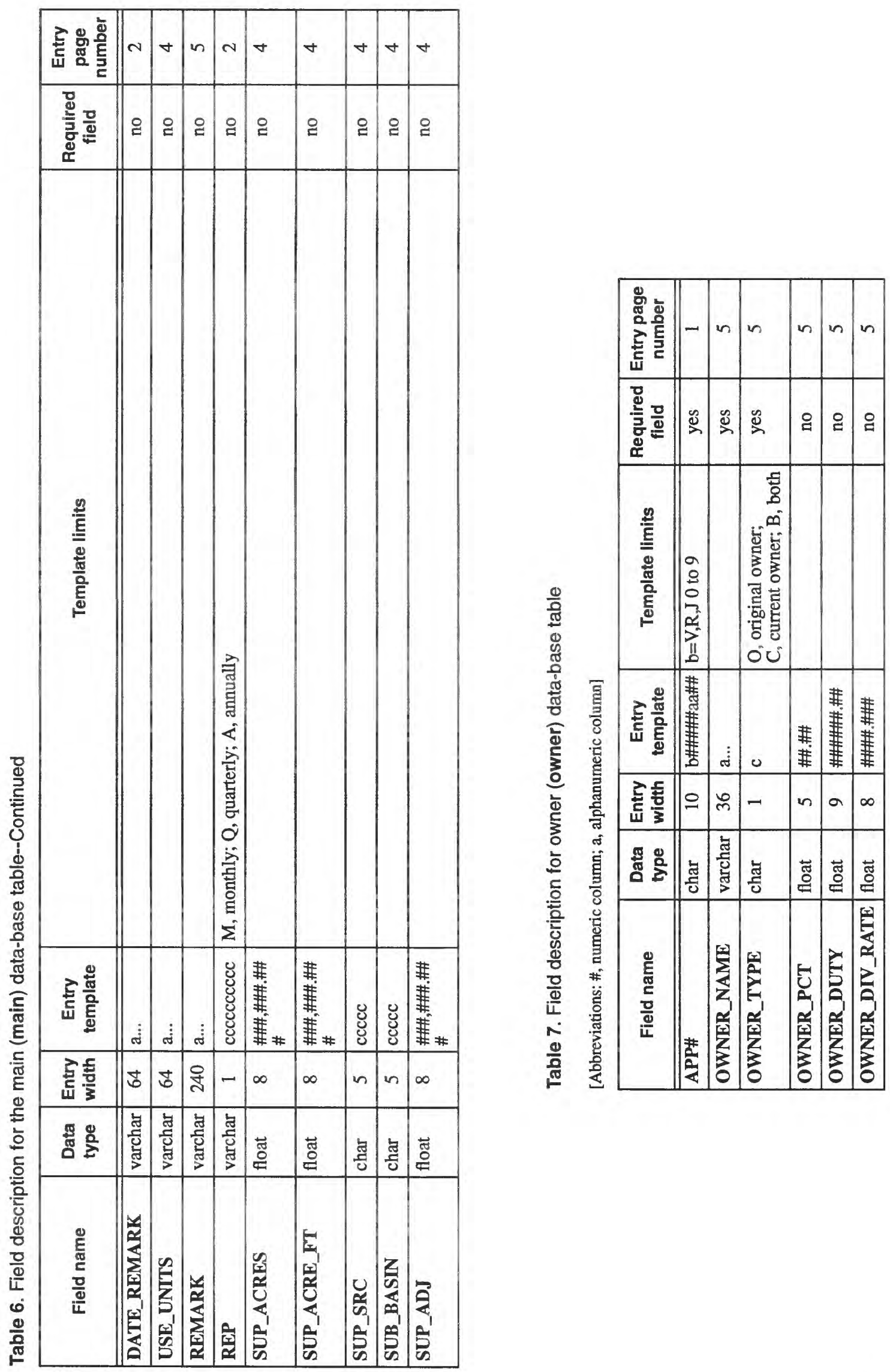
Table 8. Field description for place of use (pou) data-base table

[Abbreviations: \#, numeric column; a, alphanumeric column; c, character column]

\begin{tabular}{|c|c|c|c|c|c|c|}
\hline Field name & $\begin{array}{l}\text { Data } \\
\text { type }\end{array}$ & $\begin{array}{l}\text { Entry } \\
\text { width }\end{array}$ & $\begin{array}{l}\text { Entry } \\
\text { template }\end{array}$ & Template limits & $\begin{array}{l}\text { Required } \\
\text { field }\end{array}$ & $\begin{array}{c}\text { Entry page } \\
\text { number }\end{array}$ \\
\hline APP\# & char & 10 & b\#\#\#аa\#\# & $\mathrm{b}=\mathrm{V}, \mathrm{R}, \mathrm{J} 0$ to 9 & yes & 1 \\
\hline POU_QQ & char & 2 & aa & $\begin{array}{l}\text { SW, southwest; NW, northwest; SE southeast; } \\
\text { NE, northeast; S2, south half; N2, north half; } \\
\text { E2, east half; W2, west half }\end{array}$ & no & 3 \\
\hline POU_Q & char & 4 & aaaa & $\begin{array}{l}\text { SW, southwest; NW, northwest; SE southeast; } \\
\text { NE, northeast; } S 2 \text {, south half; N2, north half; } \\
\text { E2, east half; W2, west half }\end{array}$ & no & 3 \\
\hline POU_SEC & char & 2 & \#\# & 01 to 36 & no & 3 \\
\hline POU_TWN & char & 4 & $\# \mathrm{cc}$ & $\begin{array}{l}\text { \#\# = } 01 \text { to } 48 \\
\text { cc=N,S, NH, SH } \\
\text { N, north; S, south; NH, north half; SH, south half }\end{array}$ & no & 3 \\
\hline POU_RNG & char & 4 & $\#$ \#cc & $\begin{array}{l}\text { \#\# }=18 \text { to } 71 \\
\text { cc = E, W, EH, WH } \\
\text { E, east; W, west; EH, east half; WH, west half }\end{array}$ & no & 3 \\
\hline POU_REF & char & 3 & $\operatorname{ccc}$ & $\begin{array}{l}\text { MD, Mount Diablo; SB, San Bernardino; } \\
\text { W, Willamette; GSR, Gila and Salt River; B, Boise }\end{array}$ & no & 3 \\
\hline POU_ACRE & float & 9 & \#\#\#\#.\#\#\# & & no & 3 \\
\hline
\end{tabular}

Table 9. Field description for supplemental (supplement) data-base table

[Abbreviations: \#, numeric column; a, alphanumeric column]

\begin{tabular}{|l|l|c|l|l|c|c|}
\hline \multicolumn{1}{|c|}{ Field name } & Data type & Entry width & Entry template & Template limits & Required field & Entry page number \\
\hline \hline APP\# & char & 10 & b\#\#\#aa\#\# & b=V,R,J 0 to 9 & yes & 1 \\
\hline SUPPL_APP\# & char & 10 & $\begin{array}{l}\text { b\#\#\#aa\#\# } \\
\text { aa=A-Z,\# }\end{array}$ & b=V,R,J 0 to 9 & no & 4 \\
\hline SUPPL_AMT & float & 9 & \#\#\#\#\# & & no & 4 \\
\hline
\end{tabular}

Table 10. Field description for lookup tables

\begin{tabular}{|c|c|c|c|c|}
\hline Field name & Data type & Entry width & Key field or lookup table & Entry page number \\
\hline \multicolumn{5}{|c|}{ Hydrologic Basin (basin_lut) } \\
\hline BASIN & char & 4 & key & 1 \\
\hline BASIN_NAME & varchar & 55 & lookup & 1 \\
\hline BASIN_STATUS & varchar & 17 & lookup & 1 \\
\hline REGION & char & 2 & lookup & 1 \\
\hline REGION_NAME & varchar & 24 & lookup & 1 \\
\hline \multicolumn{5}{|c|}{ County (county_lut) } \\
\hline COUNTY & char & 2 & key & 1 \\
\hline COUNTY_NAME & varchar & 11 & lookup & 1 \\
\hline \multicolumn{5}{|c|}{ Water source (source_lut) } \\
\hline SOURCE & char & 3 & key & - \\
\hline SOURCE_NAME & varchar & 20 & lookup & 1 \\
\hline \multicolumn{5}{|c|}{ Application status (status_lut) } \\
\hline APP_STATUS & char & \begin{tabular}{|c|}
3 \\
\end{tabular} & key & 1 \\
\hline APP_STATUS_NAME & varchar & 28 & lookup & 1 \\
\hline \multicolumn{5}{|c|}{ Water use (use_lut) } \\
\hline USE & char & 3 & key & 1 \\
\hline USE_NAME & varchar & 22 & lookup & 1 \\
\hline
\end{tabular}


Table 11. Codes used for county names in county_lut

\begin{tabular}{|c|l|}
\hline $\begin{array}{c}\text { County code } \\
\text { (COUNTY) }\end{array}$ & $\begin{array}{c}\text { County name } \\
\text { (COUNTY_NAME) }\end{array}$ \\
\hline \hline CC & CARSON CITY \\
CH & CHURCHILL \\
CL & CLARK \\
DO & DOUGLAS \\
EL & ELKO \\
\hline ES & ESMERALDA \\
EU & EUREKA \\
HU & HUMBOLDT \\
LA & LANDER \\
LI & LINCOLN \\
\hline LY & LYON \\
MI & MINERAL \\
NY & NYE \\
PE & PERSHING \\
ST & STOREY \\
\hline WA & WASHOE \\
WP & WHITE PINE \\
\hline
\end{tabular}

Table 12. Codes used for application status in status-lut

\begin{tabular}{|l|l|}
\hline $\begin{array}{c}\text { Application } \\
\text { status code } \\
\text { (APP_STATUS) }\end{array}$ & $\begin{array}{c}\text { Application status description } \\
\text { (APP_STATUS_NAME) }\end{array}$ \\
\hline \hline ABN & ABANDONED \\
ABR & ABROGATED \\
APP & APPLICATION \\
CAN & CANCELLED \\
CER & CERTIFICATE \\
\hline CUR & CURTAILED \\
DEC & DECREED \\
DEN & DENIED \\
EXP & EXPIRED \\
FOR & FORFEITED \\
\hline PER & PERMIT \\
REL & RELINQUISHED \\
RES & RESERVED \\
RFA & READY FOR ACTION \\
RFP & READY FOR ACTION \\
& (PROTESTED) \\
\hline RLP & RELINQUISH A PORTION \\
RVK & REVOKED \\
RVP & REVOCABLE PERMIT \\
SUS & SUSPENDED \\
VST & VESTED RIGHT \\
WDR & WITHDRAWN \\
\hline & \\
\hline
\end{tabular}

Table 13. Codes used for source names in source_lut

\begin{tabular}{|c|l|}
\hline $\begin{array}{c}\text { Source code } \\
\text { (SOURCE) }\end{array}$ & \multicolumn{1}{|c|}{$\begin{array}{c}\text { Source description } \\
\text { (SOURCE_NAME) }\end{array}$} \\
\hline \hline EFF & EFFLUENT \\
GEO & GEOTHERMAL \\
LAK & LAKE \\
OGW & OTHER GROUND WATER \\
OSW & OTHER SURFACE WATER \\
\hline RES & RESERVOIR \\
SPR & SPRING \\
STO & STORAGE \\
STR & STREAM \\
UG & UNDERGROUND \\
\hline
\end{tabular}

Table 14. Codes used for water-use names in use_lut

\begin{tabular}{|c|l|}
\hline $\begin{array}{c}\text { Use code } \\
\text { (USE) }\end{array}$ & \multicolumn{1}{|c|}{$\begin{array}{c}\text { Use description } \\
\text { (USE_NAME) }\end{array}$} \\
\hline \hline COM & COMMERCIAL \\
CON & CONSTRUCTION \\
DEC & AS DECREED \\
DOM & DOMESTIC \\
DWR & DEWATERING \\
\hline ENV & ENVIRONMENTAL \\
IND & INDUSTRIAL \\
IRC & IRRIGATTON (CAREY ACT) \\
IRD & IRRIGATTON (DLE) \\
IRR & IRRIGATION \\
\hline MM & MINING AND MILLING \\
MUN & MUNICIPAL \\
OTH & OTHER \\
PWR & POWER \\
QM & QUASI-MUNICIPAL \\
\hline REC & RECREATIONAL \\
STK & STOCKWATERING \\
STO & STORAGE \\
WLD & WILDLIFE \\
\hline
\end{tabular}




\section{GLOSSARY}

4GL. Fourth generation language. A high-level or English-like programming language.

ABF. Application by forms. Language used for the data-base application.

Abrogation. A water-permit application that changes the point of diversion, place of use, or manner of use of a previous application.

Application Number. Request for water use (other than domestic); number is assigned by NDWR at time of filing. After all legal requirements have been satisfied, the application may be permitted and subsequently certificated.

Duty. Amount of water applied for by a water-rights applicant.

MOU. Manner of water use.

PLSS. Public Land Survey System. Rectangular system of land surveys administered by the Bureau of Land Management for the Western United States.

POD. Point of diversion. The location of a water diversion.

POU. Place of use. The area of land where diverted water is used.

Proof of Beneficial Use. Proof of beneficial use is the final proof required by the terms of the permit. The filing date depends on the amount of work that the permit holder contemplated when he filed his application.

Proof of Completion. Proof of completion is normally due one and a half years after the date the permit is issued.

Supplemental. Water usage from multiple sources, where use is restricted to a fixed duty. 